\title{
Revisiting the SAR of the Antischistosomal Aryl Hydantoin (Ro 13- 3978)
}

\author{
Chunkai Wang, ${ }^{\dagger}$ Qingjie Zhao, ${ }^{\dagger}$ Mireille Vargas, ${ }^{\ddagger}{ }^{\S}$ Jeremy O. Jones, ${ }^{\|}$Karen L. White, ${ }^{\perp}$
} David M. Shackleford, ${ }^{\perp}$ Gong Chen, ${ }^{\perp}$ Jessica Saunders, ${ }^{\perp}$ Alice C. F. Ng, ${ }^{\perp}$ Francis C. K. Chiu, ${ }^{\perp}$ Yuxiang Dong, ${ }^{\dagger}$ Susan A. Charman, ${ }^{\perp}$ Jennifer Keiser, ${ }^{\ddagger}, \S$ and Jonathan L. Vennerstrom* ${ }^{* \dagger} \dagger$

${ }^{\dagger}$ College of Pharmacy, University of Nebraska Medical Center, 986125 Nebraska Medical Center, Omaha, Nebraska 68198, United States

${ }^{\ddagger}$ Department of Medical Parasitology and Infection Biology, Swiss Tropical Institute, Socinstrasse 57, CH-4002 Basel, Switzerland

${ }^{\S}$ University of Basel, CH-4003 Basel, Switzerland

"Department of Cancer Biology, Beckman Research Institute, City of Hope National Medical Center, Duarte, California 91010, United States

${ }^{\perp}$ Centre for Drug Candidate Optimisation, Monash Institute of Pharmaceutical Sciences, Monash University (Parkville Campus), 381 Royal Parade, Parkville, Victoria 3052, Australia

Supporting Information

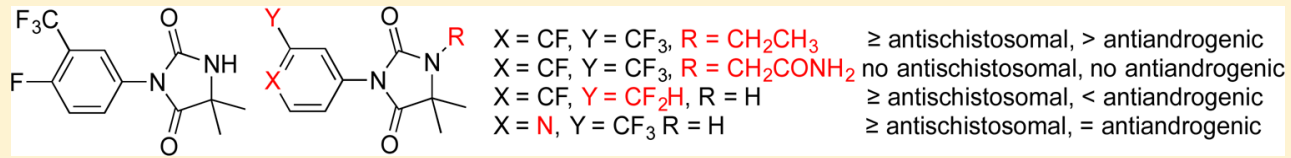

ABSTRACT: The aryl hydantoin 1 (Ro 13-3978) was identified in the early 1980s as a promising antischistosomal lead compound. However, this series of aryl hydantoins produced antiandrogenic side effects in the host, a not unexpected outcome given their close structural similarity to the antiandrogenic drug nilutamide. Building on the known SAR of this compound series, we now describe a number of analogs of $\mathbf{1}$ designed to maximize structural diversity guided by incorporation of substructures and functional groups known to diminish ligand-androgen receptor interactions. These analogs had calculated polar surface area (PSA), measured $\log \mathrm{D}_{7.4}$, aqueous kinetic solubility, and estimated plasma protein binding values in ranges predictive of good ADME profiles. The principal SAR insight was that the hydantoin core of $\mathbf{1}$ is required for high antischistosomal activity. We identified several compounds with high antischistosomal efficacy that were less antiandrogenic than 1. These data provide direction for the ongoing optimization of antischistosomal hydantoins.

S chistosomiasis is a tropical parasitic disease caused by infections with flukes of the genus Schistosoma. ${ }^{1}$ Of these, Schistosoma mansoni, S. hematobium, and S. japonicum cause the largest public health burden. ${ }^{2,3}$ Praziquantel (PZ) is the only drug available for treatment of this disease. ${ }^{4-6}$ The high drug pressure from the widespread administration of $\mathrm{PZ}$ could lead to problematic drug resistance. ${ }^{7,8}$ Even so, the discovery of a new drug for schistosomiasis continues to elude us, although several antischistosomal lead compounds and repurposed drugs have been identified in recent years. ${ }^{9-14}$

The introduction of $\mathrm{PZ}$ in 1982 likely led to decisions to abandon the development of a number of promising antischistosomal agents that were discovered during the same time period. One of these was 1 (Ro 13-3978) (Figure 1), the lead compound from a series of aryl hydantoins that were investigated in some detail at Hoffmann La-Roche. ${ }^{15-18}$ As reported by Link and Stohler, ${ }^{18} \mathbf{1}$ has high oral efficacy against all three major schistosome species-S. mansoni, S. hematobium, and $S$. japonicum - in a range of animal models. Confirming these data, we found that $\mathbf{1}$ had single oral dose $\mathrm{ED}_{50}$ values of 15 and $140 \mathrm{mg} / \mathrm{kg}$ against adult and juvenile $S$. mansoni in a

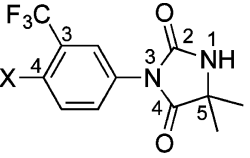

Ro 13-3978 (1), $X=F$ Nilutamide $(\mathrm{N}), X=\mathrm{NO}_{2}$

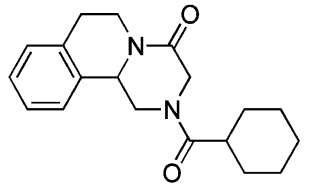

Praziquantel (PZ)
Figure 1.

mouse model. ${ }^{19}$ In this same schistosome mouse model, PZ is considerably less effective against adult S. mansoni, with reported $\mathrm{ED}_{50}$ values ranging from 172 to $202 \mathrm{mg} / \mathrm{kg}$, ${ }^{18,20}$ and it has no significant activity against juvenile stages of the parasite. Despite the high in vivo antischistosomal efficacy of $\mathbf{1}$, we found that this aryl hydantoin at concentrations up to 170 $\mu \mathrm{M}$ had almost no effect on adult $S$. mansoni in vitro. ${ }^{19}$ Data generated so far indicate that active metabolites do not account

Received: September 21, 2016

Published: November 15, 2016 
for the striking difference between the in vitro and in vivo antischistosomal activity of $\mathbf{1} .^{19}$

However, this series of aryl hydantoins produced antiandrogenic side effects in the host, ${ }^{15}$ a not unexpected outcome given their close structural similarity to the antiandrogenic drug nilutamide $(\mathrm{N})$. We recently demonstrated that $\mathrm{N}$, but not the three structurally diverse androgen receptor (AR) antagonists flutamide, bicalutamide, and cyproterone acetate, has weak, but measurable, antischistosomal activity in S. mansoni-infected mice. $^{21}$ As phylogenetic evidence indicates that schistosome species do not appear to have AR's, ${ }^{22}$ these data led us to hypothesize that, for aryl hydantoins and related heterocycles, the structural requirements for antischistosomal efficacy and $\mathrm{AR}$ binding interactions are divergent. In this respect, 1 had no measurable interaction with the $\mathrm{AR}$ in a ligand competition assay, but it did block DHT-induced cell proliferation in an androgen-dependent cell line. ${ }^{23}$ Despite its antiandrogenic liability, Link and Stohler ${ }^{18}$ observed no apparent toxicity following administration of a single $1250 \mathrm{mg} / \mathrm{kg}$ dose of 1 to mice.

Highlights from the SAR of this aryl hydantoin compound series conducted by Hoffmann La-Roche ${ }^{18}$ are (1) a combination of halogens $(\mathrm{F}, \mathrm{Cl})$ and/or $\mathrm{CF}_{3}$ groups at positions 3 and 4 of the phenyl ring was optimal; (2) electron-donating groups such as methoxy and dimethylamino at these same positions diminished activity; (3) 4-imino derivatives were active; and (4) some $N^{1}$-substituted analogs were active. Building on this foundation, we now describe a number of analogs of $\mathbf{1}(\mathbf{2}-\mathbf{3 6}$, Tables 1-4) designed to maximize structural diversity guided by incorporation of substructures and functional groups known to diminish ligand-AR interactions. For example, several target compounds maintain the 5,5-dimethylhydantoin core of $\mathbf{1}$ and incorporate phenethyl (6), sulfonamide $(7,8)$, aromatic halogens (10), and $\mathrm{C}=\mathrm{N}$ bonds $(15-20)$, functional groups and structural elements demonstrated to abolish or diminish AR ligand affinity. ${ }^{24-28}$ The final set of target compounds maintains the 4fluoro-3-trifluoromethylphenyl substructure of $\mathbf{1}$ in heterocycle variants of the 5,5-dimethylhydantoin substructure: succinimide 29 , oxazolidinedione 30 , oxolactam 31 , urea 32 , hydantoin transpositional isomer 33 , and the ring-expanded dihydropyrimidinediones 34 and 35 . Hydantoins analogous to 33 had relatively weak AR binding affinity. ${ }^{24}$ We now report physicochemical profiling, in vitro ADME, antiandrogenic assessment, plasma exposure, and in vivo antischistosomal activities of these compounds.

\section{CHEMISTRY}

$N^{1}$-Alkyl and aralkyl hydantoins 2-6 and sulfonamides 7 and 8 were obtained by $N$-alkylation and sulfonylation of $\mathbf{1}$ according to the methods of Van Dort and Jung ${ }^{28}$ and Jung et al. ${ }^{24}$ (Scheme 1). Urea carboxylic acid 36 was obtained in high yield by hydrolysis of 1 with aqueous $\mathrm{NaOH}$ followed by acidification with dilute $\mathrm{HCl}$.

Target compounds 11-13, 16, 17, 19, and 20 were obtained in variable yields by high-temperature reactions of the corresponding aryl iodides (37-41, 43, and 44) and hyantoin 42 with cuprous oxide ${ }^{29,30}$ in dimethylacetamide (DMA) (Scheme 2).

Reactions between aryl iodide 45 and spiro hydantoin 46 or succinimide 47 under these same conditions afforded 27 and 29, respectively (Scheme 3). Similarly, 14 was obtained by copper-catalyzed coupling of aryl bromide 49 and 42, whereas
Scheme $1^{a}$

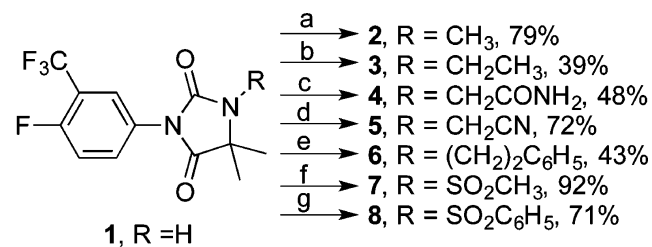<smiles>CC(C)(NC(=O)Nc1ccc(F)c(C(F)(F)F)c1)C(=O)O</smiles>

$36,95 \%$

${ }^{a}$ Reagents and conditions: (a) NaH, DMF, rt, 0.5 h, then MeI, rt, 2 h; (b) $\mathrm{NaH}$, THF, $0{ }^{\circ} \mathrm{C}$ to rt, $0.5 \mathrm{~h}$, then EtI, rt, $3 \mathrm{~d}$; (c) NaH, THF, $0{ }^{\circ} \mathrm{C}$ to rt, $0.5 \mathrm{~h}$, then 2-bromoacetamide, rt, $3 \mathrm{~d}$; (d) NaH, DMF, rt, $0.5 \mathrm{~h}$, then 2-bromoacetonitrile, rt, $2 \mathrm{~h}$; (e) NaH, DMF, rt, $0.5 \mathrm{~h}$, then 2bromoethylbenzene, rt, $2 \mathrm{~h}$; (f) $\mathrm{NaH}$, THF, $0{ }^{\circ} \mathrm{C}$ to $\mathrm{rt}, 0.5 \mathrm{~h}$, then $\mathrm{MeSO}_{2} \mathrm{Cl}$, rt, $3 \mathrm{~d}$; $(\mathrm{g}) \mathrm{NaH}, \mathrm{DMF}, \mathrm{rt}, 0.5 \mathrm{~h}$, then benzenesulfonyl chloride, rt, $2 \mathrm{~h}$; (h) $2 \mathrm{M} \mathrm{NaOH}$, rt, 4 h, then $2 \mathrm{M} \mathrm{HCl}$.

Scheme $2^{a}$

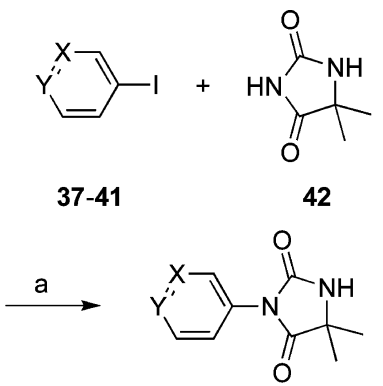

11, $\mathrm{X}=\mathrm{CCF}_{3}, \mathrm{Y}=\mathrm{CCH}_{3}, 54 \%$

12, $X=\mathrm{CCN}, Y=\mathrm{CF}, 77 \%$

13, $X=\mathrm{CCON}\left(\mathrm{CH}_{3}\right)_{2}, \mathrm{Y}=\mathrm{CF}, 58 \%$

16, $X=\mathrm{CCF}_{3}, Y=\mathrm{N}, 90 \%$

19, $\mathrm{X}=\mathrm{N}, \mathrm{Y}=\mathrm{CCF}_{3}, 75 \%$
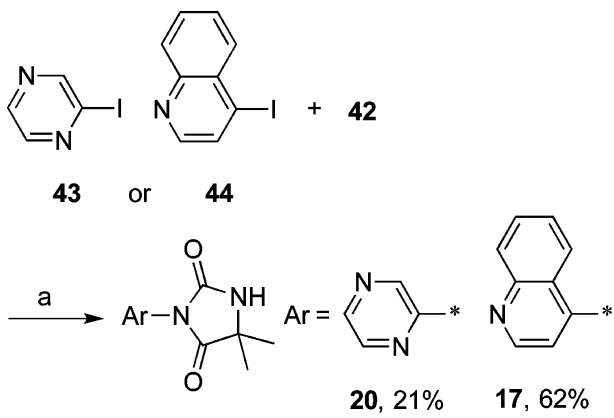

${ }^{a}$ Reagents and conditions: (a) $\mathrm{Cu}_{2} \mathrm{O}, \mathrm{DMA}, 140-160{ }^{\circ} \mathrm{C} ; 12-72 \mathrm{~h}$.

21 was obtained by alkylation of benzyl bromide 50 with $\mathbf{4 2}$ (Scheme 4). Compound 32 was obtained in a palladiumcatalyzed $N$-arylation reaction ${ }^{31}$ between aryl iodide 45 and imidazolidin-2-one $\mathbf{4 8}^{32}$ (Scheme 3 ).

$\mathrm{N}$-Arylation via copper(II) acetate promoted cross-coupling $^{33-35}$ of boronic acids 51 and 52 with 42 afforded 18 and 15; the same cross-coupling reaction between boronic acid 53 and 1,3-oxazolidine-2,4-dione $\mathbf{5 4}$ or bicyclic hydantoin $\mathbf{5 5}$ afforded $\mathbf{3 0}$ and $\mathbf{2 8}$, respectively (Scheme 5). 
Scheme $3^{a}$

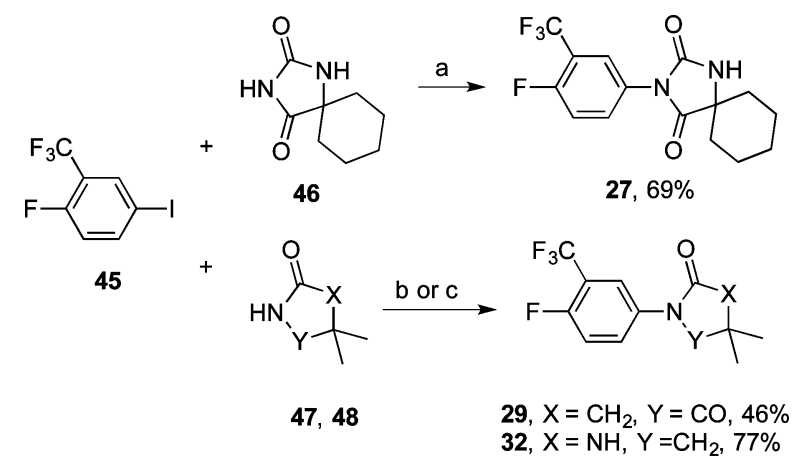

${ }^{a}$ Reagents and conditions: (a) $\mathrm{Cu}_{2} \mathrm{O}$, DMA, $160{ }^{\circ} \mathrm{C} ; 24 \mathrm{~h}$; (b) $\mathrm{Cu}_{2} \mathrm{O}$, $\mathrm{DMF}, 160{ }^{\circ} \mathrm{C} ; 48 \mathrm{~h}(29)$; (c) $\mathrm{Pd}_{2}(\mathrm{dba})_{3}$, Xanthphos, $\mathrm{Cs}_{2} \mathrm{CO}_{3}$, toluene, $90{ }^{\circ} \mathrm{C} ; 12 \mathrm{~h}(32)$.

\section{Scheme $4^{a}$}

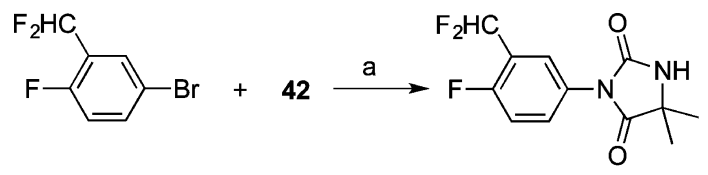

49

$14,81 \%$

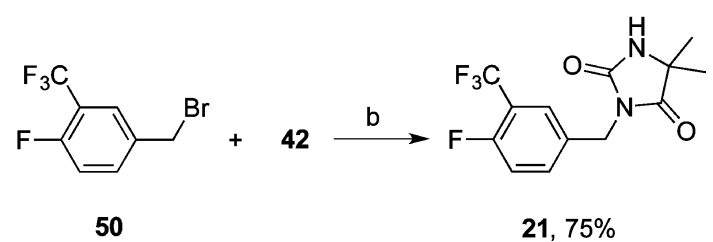

${ }^{a}$ Reagents and conditions: (a) $\mathrm{Cu}_{2} \mathrm{O}, \mathrm{DMA}, 160{ }^{\circ} \mathrm{C}, 24 \mathrm{~h}$; (b) $\mathrm{K}_{2} \mathrm{CO}_{3}$, DMA, $85^{\circ} \mathrm{C} ; 24 \mathrm{~h}$.

Scheme $5^{a}$<smiles>[Y][X]1cccc(B(O)O)c1</smiles><smiles>[Y]c1ccc(N2C(=O)NC(C)(C)C2=O)cc1</smiles>

18, $X=N, Y=C H, 61 \%$ 15, $X=\mathrm{CH}, Y=N, 47 \%$<smiles>CC1(C)OC(=O)N(c2ccc(F)c(C(F)(F)F)c2)C1=O</smiles>

${ }^{a}$ Reagents and conditions: (a) $\mathrm{Cu}(\mathrm{OAc})_{2}, \mathrm{MeOH}, \mathrm{O}_{2}, 70{ }^{\circ} \mathrm{C} ; 12 \mathrm{~h}$; (b) $\mathrm{Cu}(\mathrm{OAc})_{2}$, pyridine, $\mathrm{CH}_{2} \mathrm{Cl}_{2}, \mathrm{rt}, 7 \mathrm{~d}$.

Compounds 23-26 were obtained in a two-step sequence $e^{18,27,36}$ by reactions between aryl isocyanate $\mathbf{5 6}$ and $\alpha$ amino acids 57-60 in aqueous $\mathrm{NaOH}$ to form the corresponding urea carboxylic acids that then cyclized to the hydantoins when exposed to $2-4 \mathrm{M} \mathrm{HCl}$ at $110{ }^{\circ} \mathrm{C}$ (Scheme
6). Compounds 34 and 35 were obtained by parallel two-step reactions between 56 and $\beta$-amino acids 61 and 62 . In some

Scheme $6^{a}$

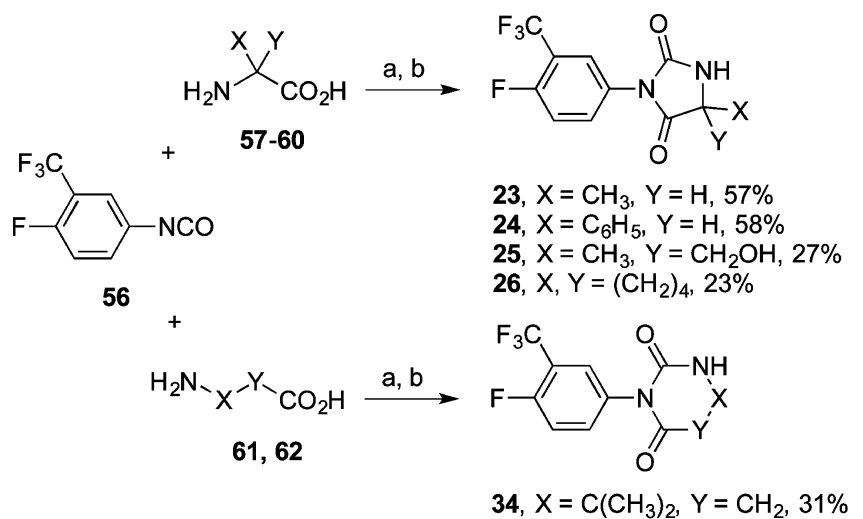

35, $\mathrm{X}=\mathrm{CH}_{2}, \mathrm{Y}=\mathrm{C}\left(\mathrm{CH}_{3}\right)_{2}, 27 \%$

${ }^{a}$ Reagents and conditions: (a) $1-2 \mathrm{M} \mathrm{NaOH}, 0{ }^{\circ} \mathrm{C}$ to rt, 3-12 h; (b) 2-4 M HCl, $110^{\circ} \mathrm{C}, 2-12 \mathrm{~h}$.

instances, the acyclic urea carboxylic acid reaction intermediates precipitated from the initial reactions after acidification, but these were not usually purified, and were converted directly to the desired hydantoin reaction products. For almost all of these reactions, small amounts of the insoluble symmetrical $\mathrm{N}, \mathrm{N}$ diarylurea derived from isocyanate $\mathbf{5 6}$ were formed.

Oxolactam 31 was obtained by cyclization of the anion of benzyl amide ester 66 in a Dieckmann-type condensation; ${ }^{37} 66$ was obtained from the corresponding acid chloride 65 (Scheme 7). The key intermediate in the synthesis of 33 was gemdimethyl $\alpha$-amino amide 64, which was obtained in a one-pot

\section{Scheme $7^{a}$}

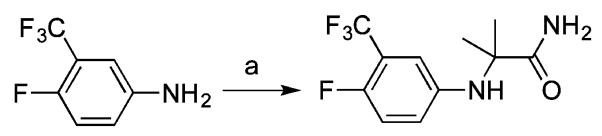

63<smiles>CCPCC(C)(C)C(F)(F)F</smiles>

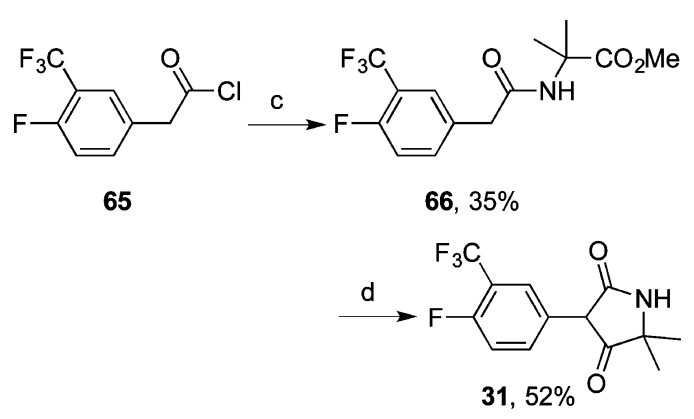

${ }^{a}$ Reagents and conditions: (a) $1 \mathrm{M} \mathrm{TiCl}_{4}$ in $\mathrm{CH}_{2} \mathrm{Cl}_{2}$, formamide, acetone, $\mathrm{CH}_{2} \mathrm{Cl}_{2}, 0{ }^{\circ} \mathrm{C}, 0.5 \mathrm{~h}$, then $\mathrm{Zn}, 50 \% \mathrm{H}_{2} \mathrm{O}_{2}$ in formamide, $0{ }^{\circ} \mathrm{C}$, $3 \mathrm{~h}$; (b) 2,6-diisopropylphenyl isocyanate, toluene, $250{ }^{\circ} \mathrm{C}, 5 \mathrm{bar}, 10$ min, MW; (c) methyl 2-amino-2-methylpropanoate $\mathrm{HCl}, \mathrm{Et}_{3} \mathrm{~N}, \mathrm{THF}$, rt, $12 \mathrm{~h}$; (d) NaH, THF, rt, $12 \mathrm{~h}$, then aq $\mathrm{AcOH}$. 
Table 1. Physicochemical, in Vitro ADME, Antiandrogenic, and Antischistosomal Data for $N^{1}$-Substituted 4-Fluoro-3trifluoromethylphenyl Hydantoins

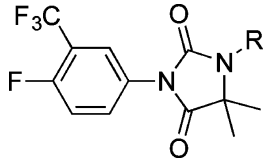

\begin{tabular}{clccccccc} 
Compd & \multicolumn{1}{c}{$\mathrm{R}$} & $\mathrm{LogD}_{7.4}{ }^{a}$ & $\begin{array}{c}\mathrm{PSA} \\
\left(\AA^{2}\right)^{b}\end{array}$ & $\begin{array}{c}\mathrm{cPPB} \\
(\%)^{c}\end{array}$ & $\begin{array}{c}\mathrm{Sol}_{2.0} / \mathrm{Sol}_{6.5} \\
(\mu \mathrm{g} / \mathrm{mL})^{d}\end{array}$ & $\begin{array}{c}\mathrm{h} / \mathrm{m} \mathrm{CL}_{\text {int }}(\mu \mathrm{L} / \mathrm{min} / \mathrm{mg} \\
\text { protein })^{e}\end{array}$ & $\begin{array}{c}\text { LAPC4 } \\
\mathrm{IC}_{50}(\mu \mathrm{M})^{f}\end{array}$ & $\begin{array}{c}\text { S. mansoni WBR (\%) } \\
\mathrm{mg} / \mathrm{kg} \mathrm{p} \mathrm{po}^{g}\end{array}$ \\
$\mathbf{1}$ & $\mathrm{H}$ & 2.7 & 49.4 & 52.1 & $>100 />100$ & $8 /<7$ & 4.4 & $95^{h}$ \\
$\mathbf{2}$ & $\mathrm{CH}_{3}$ & 3.2 & 40.6 & 40.9 & $50-100 / 50-100$ & $16 / 65$ & 1.3 & $93^{*}$ \\
$\mathbf{3}$ & $\mathrm{CH}_{2} \mathrm{CH}_{3}$ & 3.5 & 40.6 & 49.3 & $50-100 / 25-50$ & $30 / 32$ & 0.14 & $98^{*}$ \\
$\mathbf{4}$ & $\mathrm{CH}_{2} \mathrm{CONH} H_{2}$ & 2.2 & 83.7 & 20.3 & $50-100 / 50-100$ & $<7 /<7$ & agonist & 25 \\
$\mathbf{5}$ & $\mathrm{CH}_{2} \mathrm{CN}$ & 3.4 & 64.4 & 48.2 & $25-50 / 25-50$ & $\mathrm{ND}^{j}$ & 0.29 & $91^{*}$ \\
$\mathbf{6}$ & $\left(\mathrm{CH}_{2}\right)_{2} \mathrm{C}_{6} \mathrm{H}_{5}$ & 4.6 & 40.6 & 96.2 & $12.5-25 / 25-50$ & $>870 / 740$ & 2.4 & 54 \\
7 & $\mathrm{SO}_{2} \mathrm{CH}_{3}$ & 3.8 & 74.8 & 66.0 & $1.6-3.1 / 1.6-3.1$ & $<7 /<7$ & 6.3 & 19 \\
$\mathbf{8}$ & $\mathrm{SO}_{2} \mathrm{C}_{6} \mathrm{H}_{5}$ & 4.6 & 74.8 & 96.1 & $<1.6 /<1.6$ & $210 / 160$ & 4.3 & 44 \\
$\mathrm{PZ}$ & & 3.0 & 40.6 & $\mathrm{ND}$ & $>100 />100$ & $52 / 790$ & $\mathrm{ND}$ & $18^{i}$
\end{tabular}

${ }^{a} \log \mathrm{D}$ values were estimated by correlation of their chromatographic retention properties using gradient HPLC. ${ }^{46}{ }^{b}$ Calculated using ChemAxon JChem for Excel. ${ }^{c}$ Protein binding values were estimated by correlation of their chromatographic retention properties on a human albumin column. ${ }^{47}$ ${ }^{d}$ Compounds in DMSO were spiked into either $\mathrm{pH} 6.5$ phosphate buffer or $0.01 \mathrm{M} \mathrm{HCl}$ (approximately pH 2.0) and analyzed by nephelometry to determine a concentration range. ${ }^{e}$ In vitro intrinsic clearance measured in human and mouse liver microsomes. ${ }^{f}$ Cells were then exposed to $10 \mathrm{nM}$ DHT for $24 \mathrm{~h}$ in the presence of varying concentrations of test compounds. ${ }^{g}$ Groups of five $S$. mansoni-infected NMRI mice were treated on day 49 postinfection with compounds dissolved or suspended in $7 \% \mathrm{v} / \mathrm{v}$ Tween $80,3 \% \mathrm{v} / \mathrm{v}$ ethanol. At $28 \mathrm{~d}$ post-treatment, animals were sacrificed and dissected to assess total worm burden reduction (WBR). ${ }^{*} p<0.05$ from the Kruskal-Wallis test comparing the medians of the responses between the treatment and control groups. ${ }^{h}$ Data from Keiser et al. ${ }^{19}{ }^{i}$ Data from Keiser et al. ${ }^{21}{ }^{j} \mathrm{ND}=$ not determined.

Table 2. Physicochemical, in Vitro ADME, Antiandrogenic, and Antischistosomal Data for $N^{3}$-Substituted Aryl Hydantoins

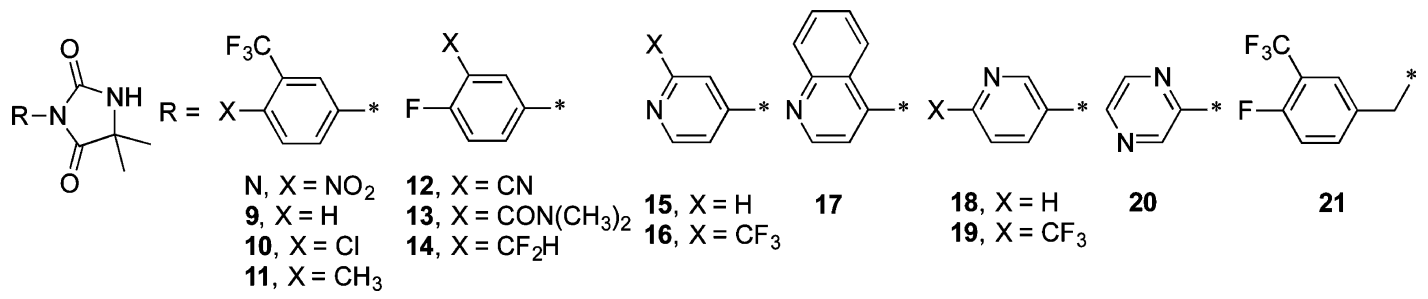

\begin{tabular}{|c|c|c|c|c|c|c|c|}
\hline Compd & $\log D_{7.4}$ & PSA $\left(\AA^{2}\right)$ & $\begin{array}{c}\mathrm{cPPB} \\
(\%)\end{array}$ & $\begin{array}{l}\mathrm{Sol}_{2.0} / \mathrm{Sol}_{6.5} \\
(\mu \mathrm{g} / \mathrm{mL})\end{array}$ & $\begin{array}{c}\mathrm{h} / \mathrm{m} \mathrm{CL}_{\text {int }}(\mu \mathrm{L} / \mathrm{min} / \mathrm{mg} \\
\text { protein })\end{array}$ & $\begin{array}{l}\mathrm{LAPC}^{\mathrm{L}} \mathrm{IC}_{50} \\
(\mu \mathrm{M})\end{array}$ & S. mansoni WBR (\%) $1 \times 100 \mathrm{mg} / \mathrm{kg}$ po \\
\hline $\mathrm{N}$ & 3.0 & 92.6 & 70.3 & $50-100 / 50-100$ & $<7 /<7$ & $0.60 / 0.45$ & $31^{a}$ \\
\hline 9 & 2.5 & 49.4 & 49.3 & $>100 />100$ & $<7 /<7$ & 6.0 & $80 *$ \\
\hline 10 & 3.0 & 49.4 & 79.6 & $>100 />100$ & $<7 /<7$ & 1.3 & $75^{* b}$ \\
\hline 11 & 2.8 & 49.4 & 64.8 & $>100 />100$ & $<7 / 16$ & $>10$ & 4.8 \\
\hline 12 & 1.7 & 73.2 & 14.6 & $>100 />100$ & $<7 /<7$ & 3.7 & 10 \\
\hline 13 & 0.9 & 69.7 & 5.9 & $>100 />100$ & $<7 /<7$ & 9.1 & 30 \\
\hline 14 & 2.2 & 49.4 & 20.4 & $>100 />100$ & $<7 /<7$ & $\geq 10$ & $94^{*}$ \\
\hline 15 & 0.5 & 62.3 & 6.7 & $50-100 />100$ & $<7 / 11$ & 3.8 & 1.8 \\
\hline 16 & 1.9 & 62.3 & 22.7 & $>100 />100$ & $<7 /<7$ & 4.5 & $100 *$ \\
\hline 17 & 1.2 & 62.3 & 16.9 & $>100 />100$ & $<7 /<7$ & 1.3 & 17 \\
\hline 18 & 0.2 & 62.3 & 6.6 & $>100 />100$ & $<7 /<7$ & 9.6 & 38 \\
\hline 19 & 1.8 & 62.3 & 18.3 & $>100 />100$ & $<7 /<7$ & $>10$ & 0 \\
\hline 20 & 0.3 & 75.2 & 5.8 & $>100 />100$ & $<7 /<7$ & $>10$ & 42 \\
\hline 21 & 2.9 & 49.4 & 82.1 & $50-100 />100$ & $17 / 11$ & 4.2 & $56^{*}$ \\
\hline
\end{tabular}

free radical multicomponent reaction ${ }^{38}$ from aniline $\mathbf{6 3}$. Exposure of 64 to 2,6-diisopropylphenyl isocyanate at high temperature ${ }^{39}$ effected carbonylative ring closure to hydantoin 33. Compounds $1,9,10$, and 22 were synthesized following procedures described by Link et al. ${ }^{18}$

\section{PHYSICOCHEMICAL AND IN VITRO ADME}

It is instructive to first consider the physicochemical and in vitro ADME properties of these analogs of $\mathbf{1}$ (Tables $1-4)$. The calculated polar surface area (PSA) values of between 32 and 84 $\AA^{2}$ indicate that the polarity of these compounds is unlikely to be a rate-limiting factor for membrane permeability and oral bioavailability. ${ }^{40}$ The measured $\log \mathrm{D}_{7.4}$ values for all but two of the compounds ranged from 0 to 4 , suggesting that high lipophilicity and the resulting poor aqueous solubility are unlikely to be limiting factors for oral absorption; this was largely borne out by the fairly high aqueous kinetic solubilities of many of these compounds. Compounds with low solubilities 
Table 3. Physicochemical, in Vitro ADME, Antiandrogenic, and Antischistosomal Data for 5-Substituted 4-Fluoro-3trifluoromethylphenyl Hydantoins<smiles>[X]C1([X])NC(=O)N(c2ccc(F)c(C(F)(F)F)c2)C1=O</smiles>

22-27<smiles>O=C1C2CCCN2C(=O)N1c1ccc(F)c(C(F)(F)F)c1</smiles>

28

\begin{tabular}{|c|c|c|c|c|c|c|c|c|}
\hline Compd & $X, Y$ & $\log \mathrm{D}_{7.4}$ & $\begin{array}{l}\text { PSA } \\
\left(\AA^{2}\right)\end{array}$ & $\begin{array}{c}\text { cPPB } \\
(\%)\end{array}$ & $\operatorname{Sol}_{2.0} / \operatorname{Sol}_{6.5}(\mu \mathrm{g} / \mathrm{mL})$ & $\begin{array}{c}\mathrm{h} / \mathrm{m} \mathrm{CL}_{\text {int }}(\mu \mathrm{L} / \mathrm{min} / \mathrm{mg} \\
\text { protein })\end{array}$ & $\begin{array}{l}\text { LAPC4 } \mathrm{IC}_{50} \\
\qquad(\mu \mathrm{M})\end{array}$ & $\begin{array}{c}\text { S. mansoni WBR }(\%) 1 \times 100 \\
\mathrm{mg} / \mathrm{kg} \text { po }\end{array}$ \\
\hline 22 & $\mathrm{H}, \mathrm{H}$ & 2.0 & 49.4 & 43.6 & $>100 />100$ & $<7 / 13$ & 0.26 & 0 \\
\hline 23 & $\mathrm{CH}_{3}, \mathrm{H}$ & 2.4 & 49.4 & 38.6 & $>100 />100$ & $17 / 34$ & $>10$ & $66^{*}$ \\
\hline 24 & $\mathrm{C}_{6} \mathrm{H}_{5}, \mathrm{H}$ & 3.5 & 49.4 & 90.0 & $6.3-12.5 / 6.3-12.5$ & $22 / 181$ & 5.3 & 41 \\
\hline 25 & $\begin{array}{l}\mathrm{CH}_{3}, \\
\mathrm{CH}_{2} \mathrm{OH}\end{array}$ & 1.9 & 69.6 & 34.3 & $25-50 / 25-50$ & $<7 /<7$ & 4.8 & 0 \\
\hline 26 & $\left(\mathrm{CH}_{2}\right)_{4}$ & 3.2 & 49.4 & 70.4 & $50-100 / 50-100$ & $33 / 93$ & 0.99 & 61 \\
\hline 27 & $\left(\mathrm{CH}_{2}\right)_{5}$ & 3.5 & 49.4 & 74.9 & $3.1-6.3 / 3.1-6.3$ & $25 / 122$ & 4.2 & 42 \\
\hline 28 & & 3.0 & 40.6 & 46.0 & $25-50 / 25-50$ & $30 / 144$ & 3.5 & 0 \\
\hline
\end{tabular}

Table 4. Physicochemical, in Vitro ADME, Antiandrogenic, and Antischistosomal Data for 4-Fluoro-3-trifluoromethylphenyl Hydantoin Heterocyle Variants

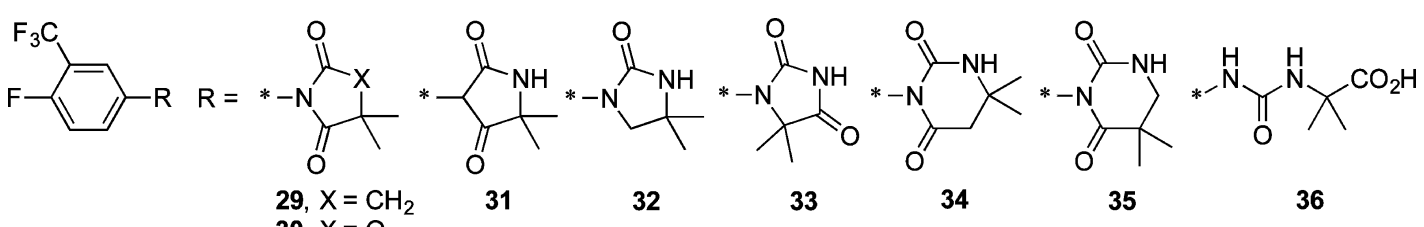

\begin{tabular}{|c|c|c|c|c|c|c|c|}
\hline Compd & $\log \mathrm{D}_{7.4}$ & $\begin{array}{l}\text { PSA } \\
\left(\AA^{2}\right)\end{array}$ & $\begin{array}{c}\mathrm{cPPB} \\
(\%)\end{array}$ & $\operatorname{Sol}_{2.0} / \operatorname{Sol}_{6.5}(\mu \mathrm{g} / \mathrm{mL})$ & $\begin{array}{c}\mathrm{h} / \mathrm{m} \mathrm{CL}_{\text {int }}(\mu \mathrm{L} / \mathrm{min} / \mathrm{mg} \\
\text { protein })\end{array}$ & $\begin{array}{l}\mathrm{LAPC} 4 \mathrm{IC}_{50} \\
(\mu \mathrm{M})\end{array}$ & S. mansoni WBR (\%) $1 \times 100 \mathrm{mg} / \mathrm{kg}$ po \\
\hline 29 & 3.4 & 37.4 & 42.5 & $12.5-25 / 12.5-25$ & $11 / 10$ & 0.91 & 42 \\
\hline 30 & 3.7 & 49.6 & 58.1 & $3.1-6.3 / 3.1-6.3$ & $12 / 12^{a}$ & 2.1 & 11 \\
\hline 31 & 0.5 & 46.2 & 93.3 & $25-50 />100$ & $<7 /<7$ & $>10$ & 0 \\
\hline 32 & 3.2 & 32.3 & 78.3 & $12.5-25 / 12.5-25$ & $<7 / 30$ & 8.1 & 59 \\
\hline 33 & 2.5 & 49.4 & 67.1 & $25-50 / 25-50$ & $<7 /<7$ & 2.8 & 0 \\
\hline 34 & 2.4 & 49.4 & 15.0 & $25-50 / 25-50$ & $<7 /<7$ & $>10$ & $51^{b}$ \\
\hline 35 & 2.5 & 49.4 & 21.5 & $12.5-25 / 12.5-25$ & $9 / 15$ & 6.9 & 19 \\
\hline 36 & 1.1 & 81.3 & 94.3 & $25-50 />100$ & $<7 /<7$ & 3.1 & 67 \\
\hline
\end{tabular}

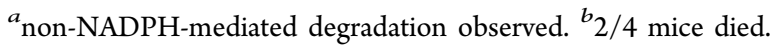

were sulfonamides 7 and 8, 5-phenylhydantoin 24, 5,5spirocyclopentylhydantoin 27, and 1,3-oxazolidine-2,4-dione 30.

The only compounds with estimated plasma protein binding values $\geq 90 \%$ were aryl sulfonamide $8, N^{1}$-phenethyl 6, 5-phenyl 24, oxolactam imide 31, and urea carboxylic acid 36. Notably, these compounds featured either additional aryl substructures $(6,8,24)$ or weak acid functional groups (31 and 36$)$. In this respect, we note that 1 , with its $\mathrm{pK}_{\mathrm{a}}$ value of $12.1{ }^{17}$ is largely un-ionized at physiological $\mathrm{pH}$. The metabolic stabilities of the $N^{1}$-alkyl and $N^{1}$-sulfonamide hydantoin derivatives (Table 1) varied from highly stable $(7)$, to intermediate $(2,3)$, to unstable $(6,8)$. For $N^{1}$-alkyl hydantoins 2 and 3 we observed $N$ dealkylation metabolic reactions to form 1. Notably, 6 and 8 , with their additional aryl groups, were the most lipophilic members of the series and also had the lowest metabolic stabilities. However, as seen for carboxamide 4, addition of polar functional groups in the $N^{1}$-alkyl substructure can increase metabolic stability. The $N^{3}$-aryl hydantoins (Table 2) and hydantoin heterocycle variants (Table 4) had high metabolic stabilities. Hydantoins substituted at the 5 position (Table 3) with combinations of methyl, hydrogen, and hydroxymethyl $(1,22,23,25)$ had high metabolic stabilities.
However, incorporation of aryl (24) or spirocycloalkyl $(26,27)$ substructures, or linking the 5 and $N^{1}$ positions by way of a pyrrolidine heterocycle (28), decreased the metabolic stabilities.

\section{ANTIANDROGENIC AND ANTISCHISTOSOMAL ACTIVITIES}

We now consider the in vitro antiandrogenic and in vivo antischistosomal properties of these analogs of 1 . The former was assessed by inhibition of dihydrotestosterone (DHT)induced androgen luciferase reporter activity in the LAPC4 cell line, a cell line with a wild-type androgen receptor (AR), and the latter by measuring worm burden reduction (WBR) in $S$. mansoni-infected mice. As we had previously observed for $\mathbf{1}$, none of the compounds at concentrations up to $100 \mu \mathrm{M}$ had activity against schistosomula or adult $S$. mansoni in vitro. Similarly, none of the compounds was cytotoxic at concentrations up to $30 \mu \mathrm{M}$ against the rat skeletal myoblast L6 cell line. Contrary to our expectation based on the previous SAR for this compound class, we did not observe decreased antiandrogenic potencies for $N^{1}$-substituted sulfonamides 7 and 8 or $N^{1}$-phenethyl 6 (Table 1). $N^{1}$-Substitution with small alkyl $(2,3)$ groups increased antiandrogenic potencies, most 
strongly for the latter. Incorporation of nitrile (5) and carboxamide (4) functional groups into the $N^{1}$-alkyl substructure had very different effects; the former was a potent antiandrogen whereas the latter had no antiandrogenic properties and was instead a weak $\mathrm{AR}$ agonist. It is known ${ }^{41}$ that hydantoins with $N^{1}$-cyanomethyl substructures are potent antiandrogens; thus, $\mathbf{5}$ served as a "negative control compound" for this SAR study. Similar to that of $\mathbf{1}, N^{1}$-substituted hydantoins 2, 3, and 5 had high antischistosomal activities; of the remaining compounds in this series, 6 had weak antischistosomal activity.

The antiandrogenic and antischistosomal properties of the $\mathrm{N}^{3}$-substituted aryl hydantoins exhibit several interesting trends (Table 2). Replacing the 4-F in $\mathbf{1}$ with a $\mathrm{NO}_{2}(\mathrm{~N})$ or $\mathrm{Cl}(\mathbf{1 0})$ increased antiandrogenic potency, whereas a $\mathrm{H}(9)$ or $\mathrm{Me}(11)$ at this same position decreased antiandrogenic potency. Of these, hydantoins $\mathbf{9}$ and $\mathbf{1 0}$ had high antischistosomal activities, similar to previously reported data. ${ }^{18}$ Replacing the 3-trifluoro in 1 with a nitrile (12) had no effect on antiandrogenic potency and abolished antischistosomal activity. However, replacing the 3-trifluoro in 1 with a tertiary carboxamide (13) or difluoromethyl (14) decreased antiandrogenic potency, and the latter had high antischistosomal activity. Hydantoin 21, the benzyl derivative of $\mathbf{1}$, had similar antiandrogenic potency but substantially reduced antischistosomal activity compared to the latter. As we had anticipated based on the known SAR for antiandrogenic hydantoins, we observed decreased antiandrogenic potencies for some of the derivatives with aromatic $\mathrm{C}=\mathrm{N}$ bonds; these included pyridines 18 and 19 and pyrazine 20. However, the only one of the $\mathrm{C}=\mathrm{N}$ containing hydantoins to have high activity against $S$. mansoni in vivo was 16, the 4pyridyl derivative with a trifluoromethyl group, which at 100 $\mathrm{mg} / \mathrm{kg}$ resulted in cure of all of the infected mice.

As the data in Table 3 illustrate, our initial foray into the SAR of the 5-position of $\mathbf{1}$ did not bear much fruit. The principle insight gained was to note that removing one, but not both, of the methyl groups (23) decreases antiandrogenic activity and retains significant antischistosomal activity. 5,5-Spirocycloalkyl derivatives 26 and 27 had measurable but insignificant worm burden reduction (WBR) values and were no less antiandrogenic than 1. Bicyclic hydantoin 28 reveals that connecting the 5 - and $N^{1}$-positions with a pyrrolidine substructure completely abolished antischistosomal activity and offered no improvement in antiandrogenic activity. Finally, the data in Table 4 shows that the hydantoin core of $\mathbf{1}$ is required for high antischistosomal efficacy. Of these, only cyclic urea 32 and urea carboxylic acid 36 had moderate antischistosomal activities. The latter is the hydrolysis product of $\mathbf{1}$ and is formed in small quantities when $\mathbf{1}$ is administered at high doses (vide infra, Figure 2a). Interestingly, as reported by Link and Stohler, ${ }^{18}$ the methyl ester of 36, with a single-dose $\mathrm{ED}_{50}$ of 62 $\mathrm{mg} / \mathrm{kg}$, has significant antischistosomal activity.

\section{MOUSE EXPOSURE}

With this compound series, we have the unusual situation where lead compounds have no in vitro activity but generally exhibit in vivo activity. Therefore, to see if there was a correlation between antischistosomal efficacy and plasma exposure and to begin to assess the effect of aryl hydantoin structure on pharmacokinetics, the most active aryl hydantoins $(1-3,14$, and 16) and three less active hydantoins $(13,23,26)$ were administered to noninfected mice at single oral doses of $100 \mathrm{mg} / \mathrm{kg}$. From a practical standpoint, it was necessary to
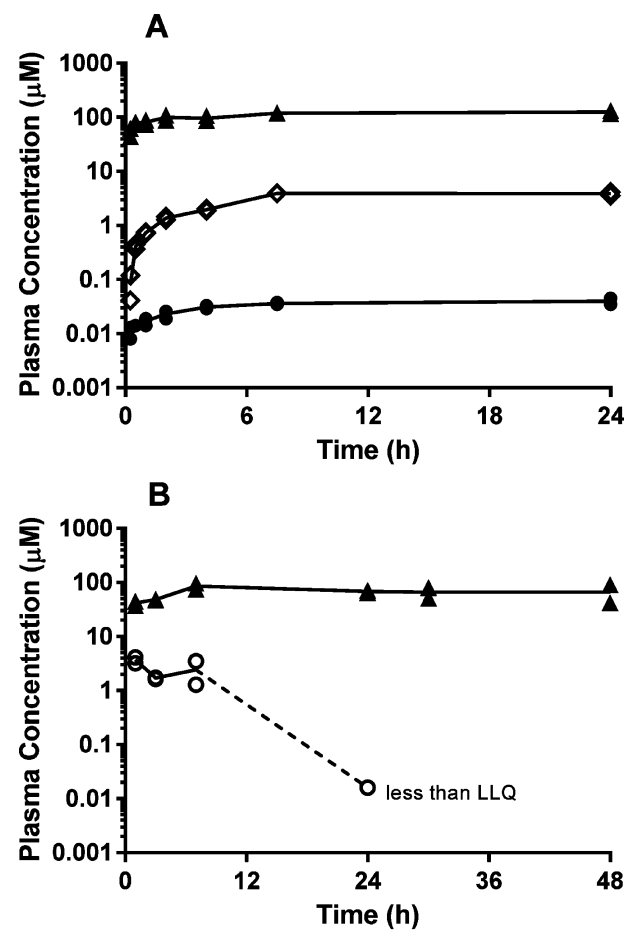

C

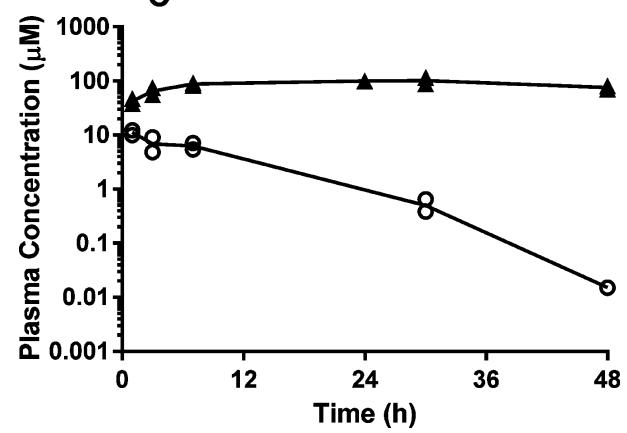

Figure 2. Plasma concentration versus time profiles of (A) 1 (filled triangles) and the metabolites 36 (filled circles) and 25 (open diamonds); (B) 2 (open circles) and the metabolite 1 (filled triangles); and (C) 3 (open circles) and the metabolite 1 (filled triangles) following oral administration of $100 \mathrm{mg} / \mathrm{kg}$ to male Swiss outbred mice. Symbols represent individual data points, and the lines represent the mean profiles.

assume that exposure profiles generated in noninfected mice provided a reasonable estimation of exposure in S. mansoniinfected mice.

After oral administration of $\mathbf{1}$, plasma concentrations increased until $2 \mathrm{~h}$ postdose, after which concentrations remained relatively constant up to $24 \mathrm{~h}$, most likely due to saturated clearance processes at the very high concentrations (Figure 2A, Table 5). We also observed low but measurable concentrations of urea carboxylic acid 36, the hydantoin hydrolysis product, and 25 , the hydroxymethyl metabolite. Based on values for $\mathrm{AUC}_{0-24 \mathrm{~h}}$, the exposures of 36 and 25 were $<1 \%$ and approximately $3 \%$, respectively, relative to $\mathbf{1}$. Following oral administration of 2 or 3 (Figure $2 \mathrm{~B}$ and $2 \mathrm{C}$ ), concentrations of the parent compounds rapidly declined with subsequent formation of $\mathbf{1}$ at maximum concentrations comparable to that seen following dosing with 1 (Figure 2A).

Hydantoins 13, 14, 16, 23, and 26 were all rapidly absorbed; however, they differed substantially in their plasma exposure profiles. The highest and most prolonged exposures were 
Table 5. Exposure Parameters for Selected Aryl Hydantoins in Male Swiss Outbred Mice Following Oral Administration of $100 \mathrm{mg} / \mathrm{kg}^{a}$

\begin{tabular}{cccc} 
Compd & $C_{\max }(\mu \mathrm{M})$ & $T_{\max }(\mathrm{h})$ & $\mathrm{AUC}_{0 \text {-last }}(\mu \mathrm{M} \cdot \mathrm{h})$ \\
$\mathbf{1}$ & 124 & c.n.d. & 2740 \\
$\mathbf{2}$ & c.n.d. & 1 & c.n.d. \\
$\mathbf{3}$ & 11.1 & 1 & 103 \\
$\mathbf{1 3}$ & 488 & 1 & 1360 \\
$\mathbf{1 4}$ & 112 & 3 & 3190 \\
$\mathbf{1 6}$ & 155 & 7 & 6480 \\
$\mathbf{2 3}$ & 26.6 & 1 & 163 \\
$\mathbf{2 6}$ & 15.0 & 1 & 106 \\
$a_{\text {c.n.d. }}=$ could not determine. & & \\
\hline
\end{tabular}

observed for 14 and 16, where plasma concentrations were comparable to those for $\mathbf{1}$ (Figure $3 \mathrm{~A}$ and Table 5). Both the maximum concentrations and the duration of exposures of 23 and 26 were substantially lower, likely due in part to their higher intrinsic clearance, as determined in mouse microsomes (Figure 3B and Table 5). While 13 reached a higher maximum plasma concentration than either 14 or 16 , concentrations declined at a much faster rate, resulting in a considerably reduced duration of exposure (Figure 3B and Table 5). As 13 had a low intrinsic clearance in mouse microsomes, its more rapid rate of elimination is likely due to its lower $\log \mathrm{D}$ value (0.9), resulting in a lower volume of distribution and, possibly, significant renal excretion.

\section{SUMMARY}

Hydantoin 1 and its analogs 2-36 had calculated polar surface area (PSA), measured $\log \mathrm{D}_{7.4}$, aqueous kinetic solubility, and estimated plasma protein binding values in ranges predictive of good ADME profiles. For $N^{1}$-alkyl and $N^{1}$-sulfonamide derivatives of $\mathbf{1}$, incorporation of polar functional groups increased metabolic stability, whereas incorporation of phenyl substructures decreased metabolic stability. However, none of these possessed both decreased antiandrogenic potency and increased antischistosomal activity. $N^{3}$-Aryl hydantoins, hydantoin heterocycle variants, and hydantoins substituted at the 5 position with combinations of methyl, hydrogen, and hydroxymethyl had high metabolic stabilities. The SAR of the $\mathrm{N}^{3}$-substituted aryl hydantoins was complex, but three of these had high antischistosomal efficacy and were less antiandrogenic than 1. The SAR of the 5-substituted aryl hydantoins reveals that replacing one of the methyl groups with a hydrogen atom decreases antiandrogenic activity and retains significant antischistosomal activity. Investigation of heterocycle variants showed that the hydantoin core of $\mathbf{1}$ is required for high antischistosomal activity. In this respect, recent investigations of a series of structurally distinct 4-thiohydantoins reveal that they have activity against $S$. mansoni in vitro; ${ }^{42}$ the best of these effected a $71 \%$ worm burden reduction (WBR) in S. mansoniinfected mice when it was administered as five daily $100 \mathrm{mg} / \mathrm{kg}$ oral doses. ${ }^{43}$

Exposure data for selected compounds reveals the following. First, $N^{1}$-alkyl hydantoins 2 and 3 had high antischistosomal activities, due most likely to their extensive conversion to 1 by metabolic $N$-dealkylation reactions. Second, $N^{3}$-aryl hydantoins 14 and 16, two of the most active compounds, had, like 1, high plasma exposures; conversely, $\mathrm{N}^{3}$-aryl hydantoin 13, 5-methyl hydantoin 23, and 5,5-dispirocyclopentyl hydantoin 26, three less effective compounds, had relatively low plasma exposures. These data are suggestive that antischistosomal efficacy and plasma exposure may correlate. This study provides several insights for the ongoing identification of more effective antischistosomal hydantoins.

\section{EXPERIMENTAL SECTION}

General. All reagents were purchased from Sigma-Aldrich, Fisher, or Acros Organics and used without further purification, unless otherwise stated. Melting points were determined with a Stanford Research Systems melting point apparatus and are uncorrected. $1 \mathrm{D}{ }^{1} \mathrm{H}$ and ${ }^{13} \mathrm{C}$ NMR spectra were recorded on a Bruker $500 \mathrm{MHz}$ spectrometer using $\mathrm{CDCl}_{3}$ or DMSO- $d_{6}$ as solvents. All chemical shifts are reported in parts per million ( $\mathrm{ppm}$ ) and are relative to internal $\left(\mathrm{CH}_{3}\right)_{4} \mathrm{Si}(0 \mathrm{ppm})$ for ${ }^{1} \mathrm{H}$ and $\mathrm{CDCl}_{3}(77.2 \mathrm{ppm})$ or DMSO$d_{6}(39.5 \mathrm{ppm})$ for ${ }^{13} \mathrm{C}$ NMR. EI GC-MS data were obtained using an Agilent quadrapole mass spectrometer with $30 \mathrm{~m}$ DB-XLB type columns and a He flow rate of $1 \mathrm{~mL} / \mathrm{min}$. Silica gel (sg) particle size 32-63 $\mu \mathrm{m}$ was used for all flash column chromatography. Reported reaction temperatures are those of the oil bath. A Biotage microwave reactor was used for selected reactions. Combustion analysis confirmed that all target compounds have a purity of at least $95 \%$.

3-[4-Fluoro-3-(trifluoromethyl)phenyl]-1,5,5-trimethylimidazolidine-2,4-dione (2). To a solution of 1 (700 $\mathrm{mg}, 2.4 \mathrm{mmol})$ in DMF was added $\mathrm{NaH}(87 \mathrm{mg}, 3.6 \mathrm{mmol})$ under Ar. The mixture was stirred at $\mathrm{rt}$ for $30 \mathrm{~min}$, and then iodomethane $(514 \mathrm{mg}, 3.6 \mathrm{mmol})$ was added dropwise. After stirring for $2 \mathrm{~h}$, the mixture was evaporated in vacuo to give a residue which was extracted with brine $(30 \mathrm{~mL})$ and EtOAc (3 $\times 30 \mathrm{~mL})$. The combined organic phase was washed with brine $(2 \times$ $30 \mathrm{~mL}$ ) and dried over $\mathrm{MgSO}_{4}$. After removal of the solvents, the residue was purified by chromatography (sg, hexane:EtOAc, 4:1) to afford 2 as a white solid (580 mg, 79\%). mp $110-112{ }^{\circ} \mathrm{C} ;{ }^{1} \mathrm{H}$ NMR

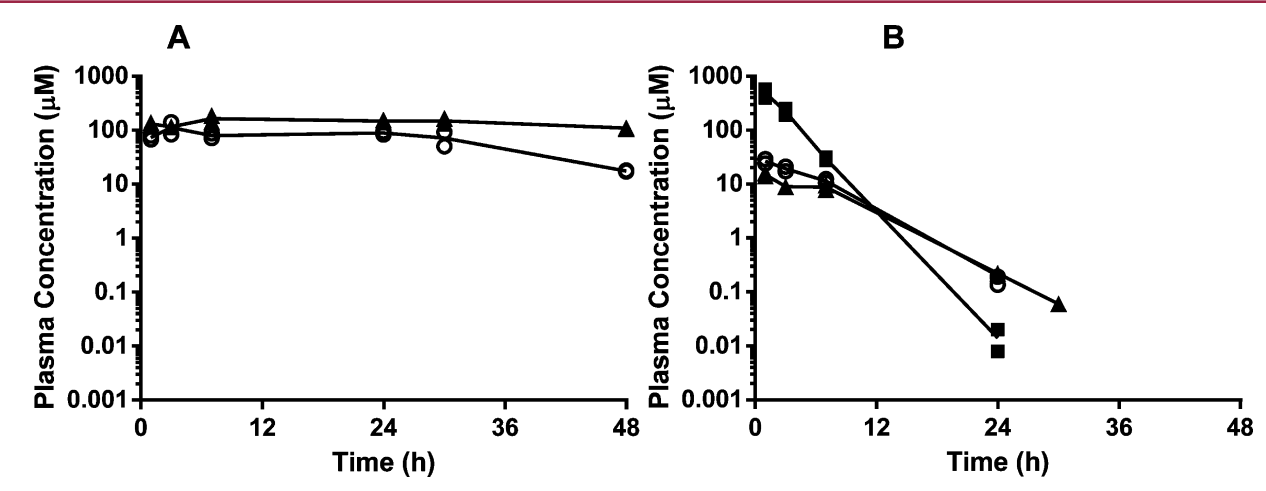

Figure 3. Plasma concentration versus time profiles of (A) 16 (filled triangles) and 14 (open circles) and (B) 13 (filled squares), 23 (open circles), and 26 (filled triangles), following oral administration of $100 \mathrm{mg} / \mathrm{kg}$ to male Swiss outbred mice. Symbols represent individual data points, and the lines represent the mean profiles. 
$\left(\mathrm{CDCl}_{3}\right) \delta 1.51(\mathrm{~s}, 6 \mathrm{H}), 2.98(\mathrm{~s}, 3 \mathrm{H}), 7.29(\mathrm{t}, J=9.3 \mathrm{~Hz}, 1 \mathrm{H}), 7.66-$ $7.69(\mathrm{~m}, 1 \mathrm{H}), 7.77(\mathrm{~d}, J=6.3 \mathrm{~Hz}, 1 \mathrm{H}) ;{ }^{13} \mathrm{C} \mathrm{NMR}\left(\mathrm{CDCl}_{3}\right) \delta 22.28$, $24.68,61.22,117.48(\mathrm{~m}), 118.96(\mathrm{qd}, J=33.6,13.9 \mathrm{~Hz}), 122.03(\mathrm{q}, J=$ $272.5 \mathrm{~Hz}), 124.80(\mathrm{~m}), 128.07(\mathrm{~d}, J=3.6 \mathrm{~Hz}), 131.23(\mathrm{~d}, J=8.6 \mathrm{~Hz})$, 153.44, $158.48(\mathrm{q}, J=258.2 \mathrm{~Hz}), 175.14$. Anal. Calcd for $\mathrm{C}_{13} \mathrm{H}_{12} \mathrm{~F}_{4} \mathrm{~N}_{2} \mathrm{O}_{2}$ : C, 51.32; H, 3.98; N, 9.21; Found: C, 51.20; H, 3.92; N, 9.39.

1-Ethyl-3-[4-fluoro-3-(trifluoromethyl)phenyl]-5,5-dimethylimidazolidine-2,4-dione (3). To a solution of $1(700 \mathrm{mg}, 2.4 \mathrm{mmol})$ in THF $(7.5 \mathrm{~mL})$ was added $\mathrm{NaH}(87 \mathrm{mg}, 3.6 \mathrm{mmol})$ in THF $(7.5 \mathrm{~mL})$ at $0{ }^{\circ} \mathrm{C}$ under Ar. The reaction mixture was then stirred at $\mathrm{rt}$ for $3 \mathrm{~h}$ before dropwise addition of iodoethane $(561 \mathrm{mg}, 3.6 \mathrm{mmol})$. The reaction mixture was stirred at $\mathrm{rt}$ for $72 \mathrm{~h}$ before quenching with acetic acid $(600 \mathrm{mg}, 10 \mathrm{mmol})$ and $\mathrm{H}_{2} \mathrm{O}(1 \mathrm{~mL})$. Solvent removal in vacuo gave a residue which was crystallized from $\mathrm{H}_{2} \mathrm{O}$. The residue was further purified by chromatography (sg, EtOAc:hexane, 1:4) to afford 3 as a white solid (301 mg, 39\%). mp 90-91 ${ }^{\circ} \mathrm{C} ;{ }^{1} \mathrm{H} \mathrm{NMR}\left(\mathrm{CDCl}_{3}\right) \delta$ $1.32(\mathrm{t}, J=7.2 \mathrm{~Hz}, 3 \mathrm{H}), 1.53(\mathrm{~s}, 6 \mathrm{H}), 3.43(\mathrm{q}, J=7.2 \mathrm{~Hz}, 2 \mathrm{H}), 7.29(\mathrm{t}$, $J=9.4 \mathrm{~Hz}, 1 \mathrm{H}), 7.65-7.74(\mathrm{~m}, 1 \mathrm{H}), 7.78(\mathrm{dd}, J=6.3,2.6 \mathrm{~Hz}, 1 \mathrm{H})$. ${ }^{13} \mathrm{C}$ NMR $\left(\mathrm{CDCl}_{3}\right) \delta 15.14,23.58,35.08,61.97,117.60(\mathrm{~d}, J=22.1$ $\mathrm{Hz}), 119.11(\mathrm{qd}, J=33.6,13.6 \mathrm{~Hz}), 122.21(\mathrm{q}, J=272.5 \mathrm{~Hz}), 124.95$ $(\mathrm{q}, J=4.5 \mathrm{~Hz}), 128.25(\mathrm{~d}, J=3.6 \mathrm{~Hz}), 131.34(\mathrm{~d}, J=8.9 \mathrm{~Hz}), 153.46$, $158.60(\mathrm{~d}, J=258.1 \mathrm{~Hz})$, 175.28. Anal. Calcd for $\mathrm{C}_{14} \mathrm{H}_{14} \mathrm{~F}_{4} \mathrm{~N}_{2} \mathrm{O}_{2}$ : C, 52.83; H, 4.43; N, 8.80. Found: C, 52.80, H, 4.60, N, 8.71.

2-[3-[4-Fluoro-3-(trifluoromethyl)phenyl]-5,5-dimethyl-2,4-dioxoimidazolidin-1-yl]acetamide (4). To a solution of 1 (1.04 g, 3.6 $\mathrm{mmol})$ in THF $(15 \mathrm{~mL})$ was added $\mathrm{NaH}(163 \mathrm{mg}, 6.8 \mathrm{mmol})$ in THF $(15 \mathrm{~mL})$ at $0{ }^{\circ} \mathrm{C}$ under Ar. The mixture was then stirred at $\mathrm{rt}$ for $3 \mathrm{~h}$ before dropwise addition of 2-bromoacetamide $(937 \mathrm{mg}, 6.8 \mathrm{mmol}$ ). The reaction mixture was stirred at $\mathrm{rt}$ for $72 \mathrm{~h}$ before quenching with acetic acid $(600 \mathrm{mg}, 10 \mathrm{mmol})$. Solvent removal in vacuo gave a residue which was crystallized from $\mathrm{CH}_{2} \mathrm{Cl}_{2}$ to afford 4 as a white solid (600 mg, 48\%). mp $186-187{ }^{\circ} \mathrm{C} ;{ }^{1} \mathrm{H}$ NMR (DMSO- $\left.d_{6}\right) \delta 1.43(\mathrm{~s}$, $6 \mathrm{H}), 3.90(\mathrm{~s}, 2 \mathrm{H}), 7.25(\mathrm{~s}, 1 \mathrm{H}), 7.50(\mathrm{~s}, 1 \mathrm{H}), 7.69(\mathrm{t}, J=9.7 \mathrm{~Hz}, 1 \mathrm{H})$, $7.80-7.86(\mathrm{~m}, 1 \mathrm{H}), 7.90(\mathrm{dd}, J=6.6,2.5 \mathrm{~Hz}, 1 \mathrm{H}) ;{ }^{13} \mathrm{C} \mathrm{NMR}$ $\left(\right.$ DMSO- $\left.d_{6}\right) \delta 22.04,41.90,61.62,116.72(\mathrm{qd}, J=32.9,13.6 \mathrm{~Hz})$, $117.84(\mathrm{~d}, J=21.8 \mathrm{~Hz}), 122.21(\mathrm{q}, J=272.4 \mathrm{~Hz}), 125.36(\mathrm{q}, J=5.0$ $\mathrm{Hz}), 128.74(\mathrm{~d}, J=3.3 \mathrm{~Hz}), 133.37(\mathrm{~d}, J=9.3 \mathrm{~Hz}), 153.50,157.56$ $(\mathrm{dq}, J=254.9,1.9 \mathrm{~Hz}), 169.63,175.02$. Anal. Calcd for $\mathrm{C}_{14} \mathrm{H}_{13} \mathrm{~F}_{4} \mathrm{~N}_{3} \mathrm{O}_{3}$ : C, 48.42; H, 3.77; N, 12.10. Found: C, 48.70, H, 4.01, N, 11.89.

2-[3-[4-Fluoro-3-(trifluoromethyl)phenyl]-5,5-dimethyl-2,4-dioxoimidazolidin-1-yl]acetonitrile (5). To a solution of 1 (700 mg, 2.4 $\mathrm{mmol})$ in DMF was added $\mathrm{NaH}(116 \mathrm{mg}, 4.8 \mathrm{mmol})$ under Ar. The mixture was stirred at $\mathrm{rt}$ for $30 \mathrm{~min}$, and then 2-bromoacetonitrile (578 $\mathrm{mg}, 4.8 \mathrm{mmol}$ ) was added dropwise. After stirring for $2 \mathrm{~h}$, the mixture was evaporated in vacuo to give a residue which was extracted with brine $(30 \mathrm{~mL})$ and EtOAc $(3 \times 30 \mathrm{~mL})$. The combined organic phase was washed with brine $(2 \times 30 \mathrm{~mL})$ and dried over $\mathrm{MgSO}_{4}$. After removal of the solvents, the residue was purified by chromatography (sg, hexane:EtOAc, 2:1) to afford 5 as a white solid (573 mg, 72\%). mp $147-149{ }^{\circ} \mathrm{C} ;{ }^{1} \mathrm{H}$ NMR $\left(\mathrm{CDCl}_{3}\right) \delta 1.65(\mathrm{~s}, 6 \mathrm{H}), 4.37(\mathrm{~s}, 2 \mathrm{H}), 7.32$ $(\mathrm{t}, J=9.3 \mathrm{~Hz}, 1 \mathrm{H}), 7.66-7.69(\mathrm{~m}, 1 \mathrm{H}), 7.75(\mathrm{dd}, J=2.4,5.9 \mathrm{~Hz}, 1 \mathrm{H})$; ${ }^{13} \mathrm{C}$ NMR $\left(\mathrm{CDCl}_{3}\right) \delta 22.75,27.14,62.11,114.73,117.81(\mathrm{~d}, J=22.1$ $\mathrm{Hz}), 119.28$ (qd, $J=33.6,13.9 \mathrm{~Hz}), 121.90(\mathrm{q}, J=273.0 \mathrm{~Hz}), 124.89$ $(\mathrm{q}, J=1.9 \mathrm{~Hz}), 127.28(\mathrm{~d}, J=4.4 \mathrm{~Hz}), 131.27(\mathrm{~d}, J=9.6 \mathrm{~Hz}), 153.13$, 158.83(q, $J=257.2 \mathrm{~Hz})$, 173.71. Anal. Calcd for $\mathrm{C}_{14} \mathrm{H}_{11} \mathrm{~F}_{4} \mathrm{~N}_{3} \mathrm{O}_{2}: \mathrm{C}$, 51.07; H, 3.37; N, 12.76; Found: C, 51.29; H, 3.60; N, 12.52 .

3-[4-Fluoro-3-(trifluoromethyl)phenyl]-5,5-dimethyl-1-phenethylimidazolidine-2,4-dione (6). To a solution of 1 (700 mg, $2.4 \mathrm{mmol})$ in DMF $(15 \mathrm{~mL})$ was added $\mathrm{NaH}(87 \mathrm{mg}, 3.6 \mathrm{mmol})$ under Ar. The mixture was stirred at $\mathrm{rt}$ for $30 \mathrm{~min}$, and then 2-bromoethylbenzene $(670 \mathrm{mg}, 3.6 \mathrm{mmol})$ was added dropwise. After stirring for $2 \mathrm{~h}$, the mixture was evaporated in vacuo to give a residue which was extracted with brine $(30 \mathrm{~mL})$ and EtOAc $(3 \times 30 \mathrm{~mL})$. The combined organic phase was washed with brine $(2 \times 30 \mathrm{~mL})$ and dried over $\mathrm{MgSO}_{4}$. After removal of the solvents, the residue was purified by chromatography (sg, hexane:EtOAc, $4: 1)$ to afford 6 as a white solid $(410 \mathrm{mg}, 43 \%) . \mathrm{mp} 98-100{ }^{\circ} \mathrm{C} ;{ }^{1} \mathrm{H}$ NMR $\left(\mathrm{CDCl}_{3}\right) \delta 1.39(\mathrm{~s}, 6 \mathrm{H})$, $3.05(\mathrm{t}, J=7.8 \mathrm{~Hz}, 2 \mathrm{H}), 3.53(\mathrm{t}, J=8.3 \mathrm{~Hz}, 2 \mathrm{H}), 7.24-7.34(\mathrm{~m}, 6 \mathrm{H})$, $7.69-7.72(\mathrm{~m}, 1 \mathrm{H}), 7.78(\mathrm{dd}, J=2.4,6.9 \mathrm{~Hz}, 1 \mathrm{H}) ;{ }^{13} \mathrm{C} \mathrm{NMR}\left(\mathrm{CDCl}_{3}\right)$ $\delta$ 23.12, 35.34, 42.23, 61.86, $117.46(\mathrm{~d}, J=22.2 \mathrm{~Hz}), 118.94(\mathrm{qd}, J=$ $33.1,13.9 \mathrm{~Hz}), 122.04(\mathrm{q}, J=272.0 \mathrm{~Hz}), 124.72(\mathrm{~m}), 126.81,128.69$, $128.81,131.14(\mathrm{~d}, J=8.5 \mathrm{~Hz}), 138.23,153.62,158.49$ (d, $J=258.2$ $\mathrm{Hz}$ ), 174.94. Anal. Calcd for $\mathrm{C}_{20} \mathrm{H}_{18} \mathrm{~F}_{4} \mathrm{~N}_{2} \mathrm{O}_{2}$ : C, 60.91; H, 4.60; N, 7.10; Found: C, 60.70; H, 4.89; N, 7.26.

3-[4-Fluoro-3-(trifluoromethyl)phenyl]-5,5-dimethyl-1(methylsulfonyl)imidazolidine-2,4-dione (7). To a solution of 1 (700 $\mathrm{mg}, 2.4 \mathrm{mmol})$ in THF $(7.5 \mathrm{~mL})$ was added $\mathrm{NaH}(100 \mathrm{mg}, 4.1 \mathrm{mmol})$ in THF $(7.5 \mathrm{~mL})$ at $0{ }^{\circ} \mathrm{C}$ under Ar. The reaction mixture was then stirred at $\mathrm{rt}$ for $30 \mathrm{~min}$ before dropwise addition of methanesulfonyl chloride $(410 \mathrm{mg}, 3.6 \mathrm{mmol})$. After further stirring at $\mathrm{rt}$ for $72 \mathrm{~h}$, the reaction was quenched with acetic acid $(4 \mathrm{~mL})$. Removal of solvents in vacuo gave a residue to which was added $\mathrm{H}_{2} \mathrm{O}(30 \mathrm{~mL})$. The resulting precipitate was filtered and crystallized from 1:5 EtOAc:hexane to afford 7 as a white solid (812 mg, 92\%). mp 207-208 ${ }^{\circ} \mathrm{C}$; ${ }^{1} \mathrm{H}$ NMR $\left(\mathrm{CDCl}_{3}\right) \delta 1.86(\mathrm{~s}, 6 \mathrm{H}), 3.44(\mathrm{~s}, 3 \mathrm{H}), 7.35(\mathrm{t}, J=9.2 \mathrm{~Hz}, 1 \mathrm{H}), 7.67$ $(\mathrm{dt}, J=7.4,3.5 \mathrm{~Hz}, 1 \mathrm{H}), 7.75(\mathrm{dd}, J=6.1,2.7 \mathrm{~Hz}, 1 \mathrm{H}) .{ }^{13} \mathrm{C}$ NMR $\left(\mathrm{CDCl}_{3}\right) \delta 24.19,43.53,66.73,118.19(\mathrm{~d}, J=22.3 \mathrm{~Hz}), 119.70(\mathrm{qd}, J=$ $33.9,13.9 \mathrm{~Hz}), 121.95(\mathrm{q}, J=272.6 \mathrm{~Hz}), 125.36(\mathrm{qd}, J=6.9,4.5 \mathrm{~Hz})$, $126.56,131.70(\mathrm{~d}, J=9.4 \mathrm{~Hz}), 151.70,159.31(\mathrm{~d}, J=259.9 \mathrm{~Hz})$, 173.02. Anal. Calcd for $\mathrm{C}_{13} \mathrm{H}_{12} \mathrm{~F}_{4} \mathrm{~N}_{2} \mathrm{O}_{4} \mathrm{~S}$ : C, 42.39; H, 3.28; N, 7.61. Found: C, 42.40; H, 3.46; N, 7.49.

3-[4-Fluoro-3-(trifluoromethyl)phenyl]-5,5-dimethyl-1(phenylsulfonyl)imidazolidine-2,4-dione (8). To a solution of 1 (700 $\mathrm{mg}, 2.4 \mathrm{mmol})$ in DMF $(15 \mathrm{~mL})$ was added $\mathrm{NaH}(87 \mathrm{mg}, 3.6 \mathrm{mmol})$ under Ar. The mixture was stirred at $\mathrm{rt}$ for $30 \mathrm{~min}$, and then benzenesulfonyl chloride $(639 \mathrm{mg}, 3.6 \mathrm{mmol}$ ) was added dropwise. After stirring for $2 \mathrm{~h}$, the mixture was evaporated in vacuo to give a residue which was extracted with brine $(30 \mathrm{~mL})$ and EtOAc $(3 \times 30$ $\mathrm{mL})$. The combined organic phase was washed with brine $(2 \times 30$ $\mathrm{mL}$ ) and dried over $\mathrm{MgSO}_{4}$. After removal of the solvents, the residue was purified by chromatography (sg, hexane:EtOAc, 4:1) to afford 8 as a white solid $(739 \mathrm{mg}, 71 \%)$. mp $153-155{ }^{\circ} \mathrm{C} ;{ }^{1} \mathrm{H} \mathrm{NMR}\left(\mathrm{CDCl}_{3}\right) \delta$ $1.92(\mathrm{~s}, 6 \mathrm{H}), 7.27(\mathrm{t}, J=9.4 \mathrm{~Hz}, 1 \mathrm{H}), 7.57-7.71(\mathrm{~m}, 5 \mathrm{H}), 8.13(\mathrm{~d}, J=$ $8.3 \mathrm{~Hz}, 2 \mathrm{H}) ;{ }^{13} \mathrm{C}$ NMR $\left(\mathrm{CDCl}_{3}\right) \delta 24.26,66.75,117.80(\mathrm{~d}, J=22.2$ $\mathrm{Hz}$ ), 119.29 (qd, $J=34.1,13.9 \mathrm{~Hz}), 121.77(\mathrm{q}, J=272.5 \mathrm{~Hz}), 125.14$ $(\mathrm{m}), 126.46(\mathrm{~d}, J=3.8 \mathrm{~Hz}), 128.73,129.16,131.54(\mathrm{~d}, J=9.1 \mathrm{~Hz})$, $134.59,138.32,150.57,158.99$ (d, $J=259.6 \mathrm{~Hz}), 172.81$. Anal. Calcd for $\mathrm{C}_{18} \mathrm{H}_{14} \mathrm{~F}_{4} \mathrm{~N}_{2} \mathrm{O}_{4} \mathrm{~S} 0.67 \mathrm{H}_{2} \mathrm{O}$ : C, 48.87; H, 3.49; N, 6.33; Found: $\mathrm{C}$, $48.71 ; \mathrm{H}, 3.09 ; \mathrm{N}, 6.12$.

5,5-Dimethyl-3-[4-methyl-3-(trifluoromethyl)phenyl]imidazolidine-2,4-dione (11). To a solution of 5,5-dimethylimidazolidine-2,4-dione (42) $(568 \mathrm{mg}, 4.44 \mathrm{mmol})$ and $\mathrm{Cu}_{2} \mathrm{O}(240 \mathrm{mg}, 1.68$ mmol) in DMA (15 mL) was added 4-iodo-1-methyl-2(trifluoromethyl)benzene (37) (1.00 g, $3.5 \mathrm{mmol})$. After stirring at $160{ }^{\circ} \mathrm{C}$ for $12 \mathrm{~h}$, the solvent was evaporated in vacuo to give a crude product which was further purified by sg chromatography using successive elution with hexane, EtOAc, and $\mathrm{EtOH}$ to afford $\mathbf{1 1}$ as a white solid (536 mg, 54\%). mp 134-135 ${ }^{\circ} \mathrm{C} ;{ }^{1} \mathrm{H}$ NMR $\left(\mathrm{CDCl}_{3}\right) \delta$ $1.57(\mathrm{~s}, 6 \mathrm{H}), 2.51(\mathrm{~s}, 3 \mathrm{H}), 5.52(\mathrm{~s}, 1 \mathrm{H}), 7.39(\mathrm{~d}, J=8.2 \mathrm{~Hz}, 1 \mathrm{H}), 7.50$ $(\mathrm{d}, J=7.9 \mathrm{~Hz}, 1 \mathrm{H}), 7.70(\mathrm{~s}, 1 \mathrm{H}) ;{ }^{13} \mathrm{C}$ NMR $\left(\mathrm{DMSO}-d_{6}\right) \delta 18.43$, $24.65,57.85,123.92(\mathrm{q}, J=5.2 \mathrm{~Hz}), 124.09(\mathrm{q}, J=273.6 \mathrm{~Hz}), 127.54$ $(\mathrm{q}, J=29.6 \mathrm{~Hz}), 130.37,130.41,132.59,135.53,153.85,176.21$. Anal. Calcd for $\mathrm{C}_{13} \mathrm{H}_{13} \mathrm{~F}_{3} \mathrm{~N}_{2} \mathrm{O}_{2}$ : C, 54.55; H, 4.58; N, 9.79; Found: C, 54.45; $\mathrm{H}, 4.73 ; \mathrm{N}, 9.62$.

5-(4,4-Dimethyl-2,5-dioxoimidazolidin-1-yl)-2-fluorobenzonitrile (12). To a solution of $42(0.674,5.3 \mathrm{mmol})$ and $\mathrm{Cu}_{2} \mathrm{O}(290 \mathrm{mg}, 2$ mmol) in DMA (4 mL) was added 2-fluoro-5-iodobenzonitrile (38) $(1.0 \mathrm{~g}, 4.1 \mathrm{mmol})$. After it was heated to $160{ }^{\circ} \mathrm{C}$ for $48 \mathrm{~h}$, the solvent was evaporated in vacuo. After addition of EtOAc $(100 \mathrm{~mL})$, the resulting precipitate was filtered and the filtrate was concentrated and purified by chromatography (sg, EtOAc) followed by recrystallization from 1:20 ethanol: $\mathrm{H}_{2} \mathrm{O}$ to afford $\mathbf{1 2}$ as a white solid $(768 \mathrm{mg}, 77 \%)$ $\mathrm{mp} 145-147^{\circ} \mathrm{C} ;{ }^{1} \mathrm{H}$ NMR $\left(\mathrm{CDCl}_{3}\right) \delta 1.56(\mathrm{~s}, 6 \mathrm{H}), 6.70(\mathrm{~s}, 1 \mathrm{H}), 7.33$ $(\mathrm{t}, J=8.8 \mathrm{~Hz}, 1 \mathrm{H}), 7.78-7.81(\mathrm{~m}, 1 \mathrm{H}), 7.84(\mathrm{dd}, J=2.4,5.4 \mathrm{~Hz}, 1 \mathrm{H})$; ${ }^{13} \mathrm{C}$ NMR (DMSO- $\left.d_{6}\right) \delta 25.15,58.83,102.08(\mathrm{~d}, J=17.3 \mathrm{~Hz}), 112.99$, $117.08(\mathrm{~d}, J=21.1 \mathrm{~Hz}), 128.52(\mathrm{~d}, J=3.4 \mathrm{~Hz}), 130.48,132.28(\mathrm{~d}, J=$ $8.6 \mathrm{~Hz}), 154.41,161.74(\mathrm{~d}, J=261.0 \mathrm{~Hz}), 175.47$. Anal. Calcd for $\mathrm{C}_{12} \mathrm{H}_{10} \mathrm{FN}_{3} \mathrm{O}_{2}$ : C, 58.30; H, 4.08; N, 17.00; Found: C, 58.08; H, 4.26; $\mathrm{N}, 17.28$. 
5-(4,4-Dimethyl-2,5-dioxoimidazolidin-1-yl)-2-fluoro- $N, N$-dimethylbenzamide (13). To a solution of $42(640 \mathrm{mg}, 5.0 \mathrm{mmol})$ and $\mathrm{Cu}_{2} \mathrm{O}(259 \mathrm{mg}, 1.8 \mathrm{mmol})$ in DMA $(10 \mathrm{~mL})$ was added 2-fluoro-5iodo- $\mathrm{N}, \mathrm{N}$-dimethylbenzamide (39) $(496 \mathrm{mg}, 1.7 \mathrm{mmol})$. The mixture was then heated to $150{ }^{\circ} \mathrm{C}$ for $48 \mathrm{~h}$. Solvent removal in vacuo gave a crude product which was further purified by sg chromatography using successive elution with hexane, EtOAc, and ethanol followed by crystallization from a 1:10 EtOAc:hexane mixture to afford 13 as a white solid (296 mg, 58\%). mp $166-168{ }^{\circ} \mathrm{C} ;{ }^{1} \mathrm{H}$ NMR (DMSO- $d_{6}$ ) $\delta$ $1.40(\mathrm{~s}, 6 \mathrm{H}), 2.87(\mathrm{~s}, 3 \mathrm{H}), 3.01(\mathrm{~s}, 3 \mathrm{H}), 7.41(\mathrm{t}, J=9.1 \mathrm{~Hz}, 1 \mathrm{H}), 7.44$ $(\mathrm{dd}, J=6.0,2.5 \mathrm{~Hz}, 1 \mathrm{H}), 7.51$ (ddd, $J=8.9,4.8,2.6 \mathrm{~Hz}, 1 \mathrm{H}), 8.59$ (s, 1H). ${ }^{13} \mathrm{C}$ NMR (DMSO- $\left.d_{6}\right) \delta 24.68,34.33,37.85,57.85,116.21$ (d, $J$ $=23.3 \mathrm{~Hz}), 124.76(\mathrm{~d}, J=20.0 \mathrm{~Hz}), 127.11(\mathrm{~d}, J=4.7 \mathrm{~Hz}), 128.69(\mathrm{~d}$, $J=3.0 \mathrm{~Hz}), 129.62(\mathrm{~d}, J=8.7 \mathrm{~Hz}), 153.93,156.32(\mathrm{~d}, J=246.5 \mathrm{~Hz})$, 164.45, 176.27. Anal. Calcd for $\mathrm{C}_{14} \mathrm{H}_{16} \mathrm{FN}_{3} \mathrm{O}_{3}$ : C, 57.33; $\mathrm{H}, 5.50$; N, 14.33. Found: $\mathrm{C}, 57.51 ; \mathrm{H}, 5.25 ; \mathrm{N}, 14.22$.

3-[3-(Difluoromethyl)-4-fluorophenyl]-5,5-dimethylimidazolidine-2,4-dione (14). To a solution of $42(2.54 \mathrm{~g}, 19.8 \mathrm{mmol})$ and $\mathrm{Cu}_{2} \mathrm{O}(1.09 \mathrm{~g}, 7.6 \mathrm{mmol})$ in DMA $(30 \mathrm{~mL})$ was added 4-bromo-2(difluoromethyl)-1-fluorobenzene (49) (3.50 g, $15.5 \mathrm{mmol})$. After the reaction mixture was heated at $160{ }^{\circ} \mathrm{C}$ for $24 \mathrm{~h}$, the solvent was removed in vacuo. The residue was purified by chromatography (sg, EtOAc) and then crystallized successively from hexane $(15 \mathrm{~mL})$ and $\mathrm{H}_{2} \mathrm{O}(20 \mathrm{~mL})$ to afford 14 as a white solid $(3.43 \mathrm{~g}, 81 \%)$. $\mathrm{mp} 158-159$ ${ }^{\circ} \mathrm{C} ;{ }^{1} \mathrm{H}$ NMR (DMSO- $\left.d_{6}\right) \delta 1.41(\mathrm{~s}, 6 \mathrm{H}), 7.26(\mathrm{t}, J=54.1 \mathrm{~Hz}, 1 \mathrm{H})$, $7.51(\mathrm{t}, J=9.5 \mathrm{~Hz}, 1 \mathrm{H}), 7.59-7.68(\mathrm{~m}, 1 \mathrm{H}), 7.72(\mathrm{dd}, J=6.4,2.5 \mathrm{~Hz}$, $1 \mathrm{H}), 8.62(\mathrm{~s}, 1 \mathrm{H}) .{ }^{13} \mathrm{C}$ NMR (DMSO- $\left.d_{6}\right) \delta 24.60,57.85,111.52(\mathrm{td}, J$ $=236.2,3.5 \mathrm{~Hz}), 116.72(\mathrm{~d}, J=21.8 \mathrm{~Hz}), 121.46(\mathrm{td}, J=23.4,14.0$ $\mathrm{Hz}), 125.75(\mathrm{~d}, J=3.3 \mathrm{~Hz}), 128.68(\mathrm{~d}, J=3.3 \mathrm{~Hz}), 131.64(\mathrm{~d}, J=9.0$ $\mathrm{Hz}), 153.79,158.38(\mathrm{dt}, J=251.3,4.8 \mathrm{~Hz}), 176.17$. Anal. Calcd for $\mathrm{C}_{12} \mathrm{H}_{11} \mathrm{~F}_{3} \mathrm{~N}_{2} \mathrm{O}_{2}$ : C, 52.94; H, 4.07; N, 10.29. Found: C, 52.72, H, 4.19, $\mathrm{N}, 10.12$.

5,5-Dimethyl-3-(pyridin-4-yl)imidazolidine-2,4-dione (15). To a solution of $42(5.38 \mathrm{~g}, 42 \mathrm{mmol})$ and $\mathrm{Cu}(\mathrm{OAc})_{2}(543 \mathrm{mg}, 3 \mathrm{mmol})$ in methanol $(150 \mathrm{~mL})$ was added pyridin-4-ylboronic acid $(53)(3.6 \mathrm{~g}$, $29 \mathrm{mmol}$ ) under $\mathrm{O}_{2}$. The mixture was heated at $70^{\circ} \mathrm{C}$ overnight. The solvent was then filtered through silica gel to remove copper, and the resulting cake was washed with methanol $(100 \mathrm{~mL})$. Evaporation of the filtrate gave a crude product which was further purified by crystallization from a saturated $\mathrm{Na}_{2} \mathrm{CO}_{3}$ solution $(20 \mathrm{~mL})$ to afford 15 as a white solid $(2.8 \mathrm{~g}, 47 \%) . \mathrm{mp} 201-203{ }^{\circ} \mathrm{C} ;{ }^{1} \mathrm{H}$ NMR (DMSO- $d_{6}$ ) $\delta 1.42(\mathrm{~s}, 6 \mathrm{H}), 7.57(\mathrm{~d}, J=5.6 \mathrm{~Hz}, 2 \mathrm{H}), 8.67(\mathrm{~d}, J=6.1 \mathrm{~Hz}, 2 \mathrm{H}), 8.74$ (brs, $1 \mathrm{H}) .{ }^{13} \mathrm{C}$ NMR (DMSO-d $\left.d_{6}\right) \delta 24.70,57.75,119.62,139.85$, 150.26, 153.08, 175.88. Anal. Calcd for $\mathrm{C}_{10} \mathrm{H}_{11} \mathrm{~N}_{3} \mathrm{O}_{2}$ : C, 58.53; $\mathrm{H}$, 5.40; N, 20.48. Found: C, 58.14; H, 5.64; N, 20.57.

5,5-Dimethyl-3-[2-(trifluoromethyl)pyridin-4-yl]imidazolidine2,4-dione (16). To a solution of $42(776 \mathrm{mg}, 6.1 \mathrm{mmol})$ and $\mathrm{Cu}_{2} \mathrm{O}$ $(288 \mathrm{mg}, 2.0 \mathrm{mmol})$ in DMA $(30 \mathrm{~mL})$ was added 4-iodo-2(trifluoromethyl)pyridine (39) $(750 \mathrm{mg}, 2.8 \mathrm{mmol})$. After stirring at $140{ }^{\circ} \mathrm{C}$ for $24 \mathrm{~h}$, the solvent was evaporated in vacuo to give a crude product which was further purified by sg chromatography using successive elution with hexane and EtOAc to afford 16 as a white solid (674 mg, 90\%). mp 195-197 ${ }^{\circ} \mathrm{C}$; ${ }^{1} \mathrm{H}$ NMR (DMSO-d 6 ) $\delta 1.43$ (s, $6 \mathrm{H}), 7.95(\mathrm{dd}, J=5.4,1.9 \mathrm{~Hz}, 1 \mathrm{H}), 8.14(\mathrm{~d}, J=1.8,1 \mathrm{H}), 8.87(\mathrm{~d}, J=$ $5.4 \mathrm{~Hz}, 1 \mathrm{H}), 8.89$ (br s, $1 \mathrm{H}) ;{ }^{13} \mathrm{C}$ NMR (DMSO- $\left.d_{6}\right) \delta 24.61,57.82$, $116.17,121.39(\mathrm{q}, J=274.3 \mathrm{~Hz}), 122.29,141.72,146.94(\mathrm{q}, J=34.1$ $\mathrm{Hz}), 151.15,152.68$, 175.71. Anal. Calcd for $\mathrm{C}_{11} \mathrm{H}_{10} \mathrm{~F}_{3} \mathrm{~N}_{3} \mathrm{O}_{2}: \mathrm{C}, 48.36$; H, 3.69; N, 15.38. Found: C, 47.97; H, 4.00; N, 15.64 .

5,5-Dimethyl-3-(quinolin-4-yl)imidazolidine-2,4-dione (17). To a solution of $42(384 \mathrm{mg}, 3 \mathrm{mmol})$ and $\mathrm{Cu}_{2} \mathrm{O}(142 \mathrm{mg}, 1 \mathrm{mmol})$ in DMA (5 mL) was added 4-iodoquinoline (44) $(163 \mathrm{mg}, 0.64 \mathrm{mmol})$. After the reaction mixture was heated at $150{ }^{\circ} \mathrm{C}$ for $72 \mathrm{~h}$, the solvent was removed in vacuo. The residue was purified by sg chromatography using successive elution with hexane, EtOAc, and ethanol to afford 17 as a pale yellow solid $(101 \mathrm{mg}, 62 \%)$. mp $194-196{ }^{\circ} \mathrm{C} ;{ }^{1} \mathrm{H}$ NMR $\left(\right.$ DMSO- $\left.d_{6}\right) \delta 1.50(\mathrm{~s}, 3 \mathrm{H}), 1.57(\mathrm{~s}, 3 \mathrm{H}), 7.61(\mathrm{~d}, J=4.6 \mathrm{~Hz}, 1 \mathrm{H})$, $7.65-7.76(\mathrm{~m}, 2 \mathrm{H}), 7.86(\mathrm{t}, J=7.2 \mathrm{~Hz}, 1 \mathrm{H}), 8.15(\mathrm{~d}, J=8.4 \mathrm{~Hz}, 1 \mathrm{H})$, $8.83(\mathrm{~s}, 1 \mathrm{H}), 9.05(\mathrm{~d}, J=4.6 \mathrm{~Hz}, 1 \mathrm{H}) ;{ }^{13} \mathrm{C}$ NMR (DMSO- $\left.d_{6}\right) \delta 24.50$, 25.26, 58.77, 121.60, 122.83, 124.72, 127.58, 129.42, 130.15, 137.08,
148.77, 150.73, 153.60, 176.45. Anal. Calcd for $\mathrm{C}_{14} \mathrm{H}_{13} \mathrm{~N}_{3} \mathrm{O}_{2} \mathrm{H}_{2} \mathrm{O}$ : C, 61.53; H, 5.53; N, 15.38. Found: C, 61.82; H, 5.08; N, 15.30.

5,5-Dimethyl-3-(pyridin-3-yl)imidazolidine-2,4-dione (18). To a solution of $42(1.792 \mathrm{~g}, 14 \mathrm{mmol})$ and $\mathrm{Cu}(\mathrm{OAc})_{2}(181 \mathrm{mg}, 1 \mathrm{mmol})$ in methanol $(50 \mathrm{~mL})$ was added pyridin-3-ylboronic acid $(\mathbf{5 2})(1.23 \mathrm{~g}$, $10 \mathrm{mmol}$ ) under $\mathrm{O}_{2}$. The mixture was heated at $70{ }^{\circ} \mathrm{C}$ overnight. The solvent was then filtered through silica gel to remove copper, and the resulting cake was washed with methanol $(100 \mathrm{~mL})$. Evaporation of the filtrate gave a crude product which was further purified by successive crystallizations from diethyl ether $(10 \mathrm{~mL})$ and saturated $\mathrm{Na}_{2} \mathrm{CO}_{3}(10 \mathrm{~mL})$ to afford 18 as a white solid $(1.258 \mathrm{~g}, 61 \%) . \mathrm{mp}$ $160-162{ }^{\circ} \mathrm{C} ;{ }^{1} \mathrm{H}$ NMR $\left(\mathrm{CDCl}_{3}\right) \delta 1.56(\mathrm{~s}, 6 \mathrm{H}), 6.85(\mathrm{~s}, 1 \mathrm{H}), 7.43$ $(\mathrm{dd}, J=4.4,7.8 \mathrm{~Hz}, 1 \mathrm{H}), 7.84(\mathrm{~d}, J=8.3 \mathrm{~Hz}, 1 \mathrm{H}), 8.62(\mathrm{~d}, J=4.4 \mathrm{~Hz}$, $1 \mathrm{H}), 8.78(\mathrm{~s}, 1 \mathrm{H}) ;{ }^{13} \mathrm{C} \mathrm{NMR}\left(\mathrm{CDCl}_{3}\right) \delta 25.22$, 58.87, 123.57, 128.78, $133.15,146.79,148.65,154.72$, 175.79. Anal. Calcd for $\mathrm{C}_{10} \mathrm{H}_{11} \mathrm{~N}_{3} \mathrm{O}_{2}$ : C, 58.53; H, 5.40; N, 20.48; Found: C, 58.70; H, 5.36; N, 20.19.

5,5-Dimethyl-3-[6-(trifluoromethyl)pyridin-3-yl]imidazolidine2,4-dione (19). To a solution of $42(384 \mathrm{mg}, 3.00 \mathrm{mmol})$ and $\mathrm{Cu}_{2} \mathrm{O}$ $(143 \mathrm{mg}, 1.00 \mathrm{mmol})$ in DMA $(10 \mathrm{~mL})$ was added 5-iodo-2(trifluoromethyl)pyridine (41) (476 mg, $1.74 \mathrm{mmol}$ ), and the mixture was heated to $140{ }^{\circ} \mathrm{C}$ for $48 \mathrm{~h}$. After solvent removal in vacuo, the crude product was purified by sg chromatography using successive elution with hexane and EtOAc. After removal of the solvents in vacuo, the residue was crystallized from 1:20 EtOAc:hexane. The resulting precipitate was collected by filtration and rinsed by $\mathrm{H}_{2} \mathrm{O}(5 \mathrm{~mL})$ to give 19 as a white solid $(357 \mathrm{mg}, 75 \%)$. mp $173-174{ }^{\circ} \mathrm{C}$; ${ }^{1} \mathrm{H}$ NMR $\left(\right.$ DMSO- $\left._{6}\right) \delta 1.44(\mathrm{~s}, 6 \mathrm{H}), 8.08(\mathrm{~d}, J=8.3 \mathrm{~Hz}, 1 \mathrm{H}), 8.20(\mathrm{~d}, J=8.3$ $\mathrm{Hz}, 1 \mathrm{H}), 8.80(\mathrm{~s}, 1 \mathrm{H}), 8.88(\mathrm{~s}, 1 \mathrm{H}) ;{ }^{13} \mathrm{C}$ NMR (DMSO- $\left.d_{6}\right) \delta 24.80$, $58.36,121.16,121.61(\mathrm{q}, J=273.9 \mathrm{~Hz}), 132.27,135.50,144.63(\mathrm{q}, \mathrm{J}=$ 34.4 Hz), 147.43, 153.32,176.10. Anal. Calcd for $\mathrm{C}_{11} \mathrm{H}_{10} \mathrm{~F}_{3} \mathrm{~N}_{3} \mathrm{O}_{2}: \mathrm{C}$, 48.36; H, 3.69; N, 15.38. Found C, 48.48; H, 3.81; N, 15.16 .

5,5-Dimethyl-3-(pyrazin-2-yl)imidazolidine-2,4-dione (20). To a solution of $42(1.28 \mathrm{~g}, 10.0 \mathrm{mmol})$ and $\mathrm{Cu}_{2} \mathrm{O}(357.5 \mathrm{mg}, 2.5 \mathrm{mmol})$ in DMA $(20 \mathrm{~mL})$ was added 2-iodopyrazine $(43)(1.00 \mathrm{~g}, 4.9 \mathrm{mmol})$. The reaction mixture was then heated to $140{ }^{\circ} \mathrm{C}$ for $24 \mathrm{~h}$. After solvent removal in vacuo, the crude product was purified by $\mathrm{sg}$ chromatography using successive elutions with hexane, EtOAc, and ethanol. After removal of the solvents in vacuo, the residue was crystallized from a mixture of ether $(0.5 \mathrm{~mL})$ and hexane $(10 \mathrm{~mL})$. The resulting precipitate was collected by filtration to give $\mathbf{2 0}$ as a pale yellow solid (210 mg, 21\%). mp 149-151 ${ }^{\circ} \mathrm{C} ;{ }^{1} \mathrm{H}$ NMR (DMSO- $\left.d_{6}\right) \delta$ $1.44(\mathrm{~s}, 6 \mathrm{H}), 8.66-8.90(\mathrm{~m}, 4 \mathrm{H}) ;{ }^{13} \mathrm{C}$ NMR (DMSO-d 6 ) $\delta 24.65$, 58.38, 142.76, 143.72, 143.91, 144.38, 153.05, 175.80. Anal. Calcd for $\mathrm{C}_{9} \mathrm{H}_{10} \mathrm{~N}_{4} \mathrm{O}_{2} ; \mathrm{C}, 52.42 ; \mathrm{H}, 4.89 ; \mathrm{N}, 27.17$. Found: C, 52.34; H, 5.00; N, 27.21.

3-[4-Fluoro-3-(trifluoromethyl)benzyl]-5,5-dimethylimidazolidine-2,4-dione (21). A mixture of 4-(bromomethyl)-1-fluoro-2(trifluoromethyl)benzene (50) (1.552 g, $6.0 \mathrm{mmol}), 42(647 \mathrm{mg}$, $5.1 \mathrm{mmol})$, and $\mathrm{K}_{2} \mathrm{CO}_{3}(2.004 \mathrm{~g}, 14.5 \mathrm{mmol})$ in DMA $(12.5 \mathrm{~mL})$ was stirred at $85^{\circ} \mathrm{C}$ for $24 \mathrm{~h}$. The mixture was extracted with EtOAc $(3 \times$ $50 \mathrm{~mL})$ and $\mathrm{H}_{2} \mathrm{O}(50 \mathrm{~mL})$. The organic phase was combined, dried, and evaporated in vacuo to give a residue which was further purified by chromatography (sg, EtOAc:hexane, 1:3) and crystallized from $\mathrm{H}_{2} \mathrm{O}$ to afford 21 as a white solid (1.16 g, 75\%). mp 86-87 ${ }^{\circ} \mathrm{C}$; ${ }^{1} \mathrm{H}$ NMR $\left(\right.$ DMSO- $\left.d_{6}\right) \delta 1.32(\mathrm{~s}, 6 \mathrm{H}), 4.63(\mathrm{~s}, 2 \mathrm{H}), 7.50(\mathrm{dd}, J=10.7,8.6 \mathrm{~Hz}$, $1 \mathrm{H}), 7.56-7.63(\mathrm{~m}, 1 \mathrm{H}), 7.66(\mathrm{~d}, J=7.0 \mathrm{~Hz}, 1 \mathrm{H}), 8.46(\mathrm{~s}, 1 \mathrm{H}) ;{ }^{13} \mathrm{C}$ NMR (DMSO- $\left.d_{6}\right) \delta 24.53,39.91,58.03,116.53(\mathrm{qd}, J=32.4,12.6$ $\mathrm{Hz}), 117.55(\mathrm{~d}, J=20.7 \mathrm{~Hz}), 122.47(\mathrm{q}, J=272.0 \mathrm{~Hz}), 126.07(\mathrm{q}, J=$ $4.7 \mathrm{~Hz}), 133.99,134.04(\mathrm{~d}, J=5.3 \mathrm{~Hz}), 154.91,158.10(\mathrm{dq}, J=253.2$, $2.3 \mathrm{~Hz}$ ), 177.22. Anal. Calcd for $\mathrm{C}_{13} \mathrm{H}_{12} \mathrm{~F}_{4} \mathrm{~N}_{2} \mathrm{O}_{2}$ : C, 51.32; H, 3.98; N, 9.21. Found: C, 51.49; H, 4.12; N, 9.34.

3-[4-Fluoro-3-(trifluoromethyl)phenyl]-5-methylimidazolidine2,4-dione (23). Step 1. To a solution of 2-aminopropanoic acid (57) $(2.225 \mathrm{~g}, 25 \mathrm{mmol})$ in $1 \mathrm{M} \mathrm{NaOH}(40 \mathrm{~mL})$ was added 1-fluoro-4isocyanato-2-(trifluoromethyl)benzene $(56)(6.15 \mathrm{~g}, 30 \mathrm{mmol})$ in $\mathrm{CH}_{3} \mathrm{CN}(15 \mathrm{~mL})$ at $0{ }^{\circ} \mathrm{C}$ dropwise. The reaction mixture was stirred at $0{ }^{\circ} \mathrm{C}$ for $3 \mathrm{~h}$ and then warmed to rt overnight. Step 2. The reaction mixture was adjusted to $\mathrm{pH} 3.0$ by $32 \% \mathrm{HCl}$ and concentrated in vacuo. The resulting precipitate was crystallized from 1:40 EtOAc:hexane to give 2-[3-[4-fluoro-3-(trifluoromethyl)phenyl]- 
ureido]propanoic acid as a white solid (5.157 g, 70\%), $1.1 \mathrm{~g}$ (3.74 $\mathrm{mmol})$ of which was suspended in $4 \mathrm{M} \mathrm{HCl}(50 \mathrm{~mL})$ and then heated at $110{ }^{\circ} \mathrm{C}$ overnight. After the reaction mixture was cooled to $\mathrm{rt}$, the resulting precipitate was filtered to afford 23 as a white solid $(845 \mathrm{mg}$, 82\%). mp 153-154 ${ }^{\circ} \mathrm{C} ;{ }^{1} \mathrm{H}$ NMR (DMSO- $\left.d_{6}\right) \delta 1.38(\mathrm{~d}, J=6.9 \mathrm{~Hz}$, $3 \mathrm{H}), 4.27(\mathrm{q}, J=6.9 \mathrm{~Hz}, 1 \mathrm{H}), 7.65(\mathrm{t}, J=9.7 \mathrm{~Hz}, 1 \mathrm{H}), 7.76-7.83(\mathrm{~m}$, $1 \mathrm{H}), 7.87(\mathrm{dd}, J=6.7,2.5 \mathrm{~Hz}, 1 \mathrm{H}), 8.59(\mathrm{~s}, 1 \mathrm{H}) ;{ }^{13} \mathrm{C}$ NMR (DMSO$\left.d_{6}\right) \delta 16.94,52.23,116.73(\mathrm{qd}, J=32.8,13.4 \mathrm{~Hz}), 117.76(\mathrm{~d}, J=21.8$ $\mathrm{Hz}), 122.23(\mathrm{q}, J=272.1 \mathrm{~Hz}), 125.47(\mathrm{q}, J=5.1 \mathrm{~Hz}), 128.95(\mathrm{~d}, J=$ $3.5 \mathrm{~Hz}), 133.43(\mathrm{~d}, J=9.3 \mathrm{~Hz}), 154.84,157.50(\mathrm{dq}, J=254.3,2.1 \mathrm{~Hz})$, 173.81. Anal. Calcd for $\mathrm{C}_{11} \mathrm{H}_{8} \mathrm{~F}_{4} \mathrm{~N}_{2} \mathrm{O}_{2} \cdot 0.5 \mathrm{H}_{2} \mathrm{O}: \mathrm{C}, 46.33 ; \mathrm{H}, 3.18 ; \mathrm{N}$, 9.82; Found: C, 46.61; H, 3.19; N, 9.81.

(R)-3-[4-Fluoro-3-(trifluoromethyl)phenyl]-5-phenylimidazolidine-2,4-dione (24). Step 1. To a solution of (R)-2-amino-2phenylacetic acid (58) (1.057 g, $7.0 \mathrm{mmol})$ in $1 \mathrm{M} \mathrm{NaOH}(10 \mathrm{~mL})$ was added $56(2.05 \mathrm{~g}, 10 \mathrm{mmol})$ in $\mathrm{CH}_{3} \mathrm{CN}(5 \mathrm{~mL})$ at $0{ }^{\circ} \mathrm{C}$ dropwise. The mixture was stirred at $0{ }^{\circ} \mathrm{C}$ for $3 \mathrm{~h}$, and then 1,4-dioxane $(10 \mathrm{~mL})$ was added according to the method of Cooper et al. ${ }^{44}$ After stirring at $\mathrm{rt}$ for $12 \mathrm{~h}$, the reaction mixture was adjusted to $\mathrm{pH} 2$ by $32 \% \mathrm{HCl}$ and concentrated in vacuo. Step 2. The resulting precipitate was successively crystallized from 1:10 EtOH: $\mathrm{H}_{2} \mathrm{O}$ and 1:10 EtOAc:hexane to give (R)-2-[3-[4-fluoro-3-(trifluoromethyl)phenyl]ureido]-2-phenylacetic acid as a white solid $(1.661 \mathrm{~g}, 67 \%), 818 \mathrm{mg}$ of which was then suspended in $4 \mathrm{M} \mathrm{HCl}(50 \mathrm{~mL})$ and heated at $110^{\circ} \mathrm{C}$ overnight. After the reaction mixture was cooled to $0{ }^{\circ} \mathrm{C}$, the resulting precipitate was filtered to give 24 as a white solid $(678 \mathrm{mg}, 87 \%)$. mp 166-168 ${ }^{\circ} \mathrm{C}$; ${ }^{1} \mathrm{H}$ NMR (DMSO- $\left.d_{6}\right) \delta 5.37(\mathrm{~s}, 1 \mathrm{H}), 7.33-7.54(\mathrm{~m}, 5 \mathrm{H}), 7.67$ (dd, $J=10.0,9.7 \mathrm{~Hz}, 1 \mathrm{H}), 7.78-7.88(\mathrm{~m}, 1 \mathrm{H}), 7.92(\mathrm{dd}, J=6.7,2.5$ $\mathrm{Hz}, 1 \mathrm{H}), 9.10(\mathrm{~s}, 1 \mathrm{H}) .{ }^{13} \mathrm{C}$ NMR (DMSO- $\left.d_{6}\right) \delta 60.36,117.01$ (qd, $J=$ $32.8,13.5 \mathrm{~Hz}), 118.05(\mathrm{~d}, J=21.8 \mathrm{~Hz}), 122.40(\mathrm{q}, J=272.7 \mathrm{~Hz})$, $125.89,127.55,128.76,128.89,128.97(\mathrm{~d}, J=3.4 \mathrm{~Hz}), 133.80$ (d, $J=$ $9.3 \mathrm{~Hz}), 135.55,155.33,157.85(\mathrm{~d}, J=258.6 \mathrm{~Hz}), 171.60$. Anal. Calcd for $\mathrm{C}_{16} \mathrm{H}_{10} \mathrm{~F}_{4} \mathrm{~N}_{2} \mathrm{O}_{2}$ : C, 56.81; H, 2.98; N, 8.28. Found: C, 56.66; H, 3.12; N, 8.18.

3-[4-Fluoro-3-(trifluoromethyl)phenyl]-5-(hydroxymethyl)-5methylimidazolidine-2,4-dione (25). Step 1. To a solution of 2amino-3-hydroxy-2-methylpropanoic acid (59) (537 mg, $4.5 \mathrm{mmol})$ in dioxane $(23 \mathrm{~mL})$ was added $56(8.10 \mathrm{~g}, 39.5 \mathrm{mmol})$ under Ar. After the reaction mixture was stirred at $80{ }^{\circ} \mathrm{C}$ for $6 \mathrm{~h}$, it was cooled to rt, diluted with $\mathrm{CH}_{2} \mathrm{Cl}_{2}(25 \mathrm{~mL})$, and extracted with $2 \mathrm{M} \mathrm{NaOH}(3 \times 25$ $\mathrm{mL}$ ). After the combined aqueous layers were separated and filtered to remove the insoluble $\mathrm{N}, \mathrm{N}$-diarylurea side product, the filtrate was acidified with $2 \mathrm{M} \mathrm{HCl}(100 \mathrm{~mL})$ and concentrated. Step 2. The residue was suspended in $2 \mathrm{M} \mathrm{HCl}(50 \mathrm{~mL})$ and then heated at 110 ${ }^{\circ} \mathrm{C}$ for $4 \mathrm{~h}$. After the reaction mixture was cooled to $\mathrm{rt}$, the resulting precipitate was collected by filtration to give $25(370 \mathrm{mg}, 27 \%)$ as a white solid. mp $166-168{ }^{\circ} \mathrm{C} ;{ }^{1} \mathrm{H}$ NMR (DMSO- $\left.d_{6}\right) \delta 1.30(\mathrm{~s}, 3 \mathrm{H})$, $3.43(\mathrm{~d}, J=10.7 \mathrm{~Hz}, 1 \mathrm{H}), 3.67(\mathrm{~d}, J=11.2 \mathrm{~Hz}, 1 \mathrm{H}), 7.66(\mathrm{t}, J=10.3$ $\mathrm{Hz}, 1 \mathrm{H}), 7.76-7.77(\mathrm{~m}, 1 \mathrm{H}), 7.81(\mathrm{~d}, J=6.3,1 \mathrm{H}), 8.52(\mathrm{~s}, 1 \mathrm{H}) ;{ }^{13} \mathrm{C}$ NMR (DMSO- $\left.d_{6}\right)$ 18.97, 63.52, 65.38, $117.00(\mathrm{q}, J=32.5 \mathrm{~Hz}), 118.07$ $(\mathrm{d}, J=22.0 \mathrm{~Hz}), 122.40(\mathrm{q}, J=273.0 \mathrm{~Hz}), 125.20,129.15,133.29(\mathrm{~d}, J$ $=9.2 \mathrm{~Hz}), 154.78,157.61(\mathrm{~d}, J=254.2 \mathrm{~Hz}), 175.04$. Anal. Calcd for $\mathrm{C}_{12} \mathrm{H}_{10} \mathrm{~F}_{4} \mathrm{~N}_{2} \mathrm{O}_{3}$ : C, 47.07; H, 3.29; N, 9.15. Found: C, 46.91, H, 3.46, $\mathrm{N}, 9.32$.

3-[4-Fluoro-3-(trifluoromethyl)phenyl]-1,3-diazaspiro[4.4]nonane-2,4-dione (26). Step 1. To a solution of 1-aminocyclopentane-1-carboxylic acid (60) (1.161 g, $9.0 \mathrm{mmol})$ in $1 \mathrm{M}$ $\mathrm{NaOH}(15 \mathrm{~mL})$ was added a solution of $56(1.83 \mathrm{~g}, 8.9 \mathrm{mmol})$ in $\mathrm{CH}_{3} \mathrm{CN}(10 \mathrm{~mL})$ at $0{ }^{\circ} \mathrm{C}$ dropwise. The mixture was stirred at $0{ }^{\circ} \mathrm{C}$ for $3 \mathrm{~h}$ and then warmed to $\mathrm{rt}$ overnight. The reaction mixture was adjusted to $\mathrm{pH} 1.0$ by $32 \% \mathrm{HCl}$ and concentrated in vacuo. Step 2 . The resulting precipitate was collected by filtration, and the solid was then suspended in $4 \mathrm{M} \mathrm{HCl}(50 \mathrm{~mL})$ and heated at $110^{\circ} \mathrm{C}$ overnight. After the reaction mixture was cooled to $\mathrm{rt}$, the resulting precipitate was filtered and crystallized from diethyl ether to give $\mathbf{2 6}$ as a white solid (660 mg, 23\%). mp 151-152 ${ }^{\circ} \mathrm{C}$; ${ }^{1} \mathrm{H}$ NMR (DMSO- $d_{6}$ ) $\delta 1.67-$ $1.92(\mathrm{~m}, 6 \mathrm{H}), 2.01-2.16(\mathrm{~m}, 2 \mathrm{H}), 7.65(\mathrm{dd}, J=10.5,9.0 \mathrm{~Hz}, 1 \mathrm{H})$, $7.78-7.84(\mathrm{~m}, 1 \mathrm{H}), 7.90(\mathrm{dd}, J=6.6,2.6 \mathrm{~Hz}, 1 \mathrm{H}), 8.86(\mathrm{~s}, 1 \mathrm{H}) ;{ }^{13} \mathrm{C}$ NMR (DMSO- $\left.d_{6}\right) \delta 24.82,37.58,67.49,116.86$ (qd, $J=33.2,13.4$ $\mathrm{Hz}), 117.89$ (d, $J=21.9 \mathrm{~Hz}), 122.43(\mathrm{q}, J=272.4 \mathrm{~Hz}), 125.72,129.14$, $133.61(\mathrm{~d}, J=9.0 \mathrm{~Hz}), 154.16,157.65(\mathrm{~d}, J=253.1 \mathrm{~Hz}), 176.55$. Anal. Calcd for $\mathrm{C}_{14} \mathrm{H}_{12} \mathrm{~F}_{4} \mathrm{~N}_{2} \mathrm{O}_{2}$ : C, 53.17; H, 3.82; N, 8.86. Found: C, 52.89; $\mathrm{H}, 4.00 ; \mathrm{N}, 8.89$.

3-[4-Fluoro-3-(trifluoromethyl)phenyl]-1,3-diazaspiro[4.5]decane-2,4-dione (27). To a solution of 1,3-diazaspiro[4.5]decane2,4-dione (46) $(840 \mathrm{mg}, 5.0 \mathrm{mmol})$ and $\mathrm{Cu}_{2} \mathrm{O}(290 \mathrm{mg}, 2.0 \mathrm{mmol})$ in DMA $(20 \mathrm{~mL})$ was added 1-fluoro-4-iodo-2-(trifluoromethyl)benzene (45) $(1170 \mathrm{mg}, 4.0 \mathrm{mmol})$. After it was heated at $160^{\circ} \mathrm{C}$ for $24 \mathrm{~h}$, the solvent was evaporated in vacuo. The residue was purified by sg chromatography (EtOAc) to afford 27 as a white solid (917 mg, 69\%). $\mathrm{mp} 213-215^{\circ} \mathrm{C} ;{ }^{1} \mathrm{H}$ NMR (DMSO- $\left.d_{6}\right) \delta 1.25-1.40(\mathrm{~m}, 1 \mathrm{H}) 1.58(\mathrm{br}$ s, $3 \mathrm{H}) 1.64-1.83(\mathrm{~m}, 6 \mathrm{H}) 7.65(\mathrm{t}, J=9.7 \mathrm{~Hz}, 1 \mathrm{H}), 7.77-7.84(\mathrm{~m}$, 1H) $7.89(\mathrm{~d}, J=6.35 \mathrm{~Hz}, 1 \mathrm{H}) 9.05(\mathrm{br} \mathrm{s}, 1 \mathrm{H}) ;{ }^{13} \mathrm{C}$ NMR (DMSO-d $\left.)_{6}\right)$ $\delta 20.93,24.56,33.33,61.27,116.88(\mathrm{qd}, J=33.0,13.3), 117.9(\mathrm{~d}, J=$ 22.0 ), 122.4 (q, $J=272.5$ ), 125.87 (d, $J=4.1$ ), $129.03,133.76$ (d, $J=$ 9.2), 154.27, 157.7 (d, $J=254.7)$, 175.64. Anal. Calcd for $\mathrm{C}_{15} \mathrm{H}_{14} \mathrm{~F}_{4} \mathrm{~N}_{2} \mathrm{O}_{2}$ : C, 54.55; H, 4.27; N, 8.48. Found: C, 54.38; H, 4.40; N, 8.49 .

2-[4-Fluoro-3-(trifluoromethyl)phenyl]tetrahydro-1H-pyrrolo[1,2c]imidazole-1,3(2H)-dione (28). To a solution of tetrahydro- $1 \mathrm{H}$ pyrrolo[1,2-c]imidazole-1,3(2H)-dione $(\mathbf{5 5})(538 \mathrm{mg}, 3.8 \mathrm{mmol})$, $\mathrm{Cu}(\mathrm{OAc})_{2}(1.370 \mathrm{~g}, 7.6 \mathrm{mmol})$, and pyridine $(900 \mathrm{mg}, 11.4 \mathrm{mmol})$ in $\mathrm{CH}_{2} \mathrm{Cl}_{2}(38 \mathrm{~mL})$ was added [4-fluoro-3-(trifluoromethyl)phenyl]boronic acid (53) $(2.359 \mathrm{~g}, 11.3 \mathrm{mmol})$. After stirring at rt for 7 days, the solvent was removed in vacuo. The residue was purified by chromatography (sg, EtOAc) and then crystallized from hexane to afford 28 as a white solid (443 mg, 39\%). mp 146-148 ${ }^{\circ} \mathrm{C} ;{ }^{1} \mathrm{H}$ NMR $\left(\mathrm{CDCl}_{3}\right) \delta 1.78-1.93(\mathrm{~m}, 1 \mathrm{H}), 2.06-2.30(\mathrm{~m}, 2 \mathrm{H}), 2.32-2.45(\mathrm{~m}$, $1 \mathrm{H}$ ), 3.37 (ddd, $J=11.6,8.5,4.6 \mathrm{~Hz}, 1 \mathrm{H}), 3.80(\mathrm{dt}, J=11.5,7.8 \mathrm{~Hz}$, $1 \mathrm{H}), 4.27(\mathrm{dd}, J=9.4,7.5 \mathrm{~Hz}, 1 \mathrm{H}), 7.29(\mathrm{t}, J=9.3 \mathrm{~Hz}, 1 \mathrm{H}), 7.60-7.68$ $(\mathrm{m}, 1 \mathrm{H}), 7.74(\mathrm{dd}, J=6.2,2.6 \mathrm{~Hz}, 1 \mathrm{H}) ;{ }^{13} \mathrm{C}$ NMR $\left(\mathrm{DMSO}-d_{6}\right) \delta$ 26.38, 26.50, 45.30, 62.94, 116.77 (qd, $J=33.1,13.5 \mathrm{~Hz}), 117.87$ (d, $J$ $=21.8 \mathrm{~Hz}), 122.20(\mathrm{q}, J=272.0 \mathrm{~Hz}), 125.68,128.89(\mathrm{~d}, J=3.4 \mathrm{~Hz})$, 133.59 (d, $J=9.4 \mathrm{~Hz}), 157.66(\mathrm{~d}, J=255.0 \mathrm{~Hz}), 158.26,172.45$. Anal. Calcd for $\mathrm{C}_{13} \mathrm{H}_{10} \mathrm{~F}_{4} \mathrm{~N}_{2} \mathrm{O}_{2}$ : C, 51.66; H, 3.34; N, 9.27. Found: C, 51.70; $\mathrm{H}, 3.40 ; \mathrm{N}, 9.55$.

1-[4-Fluoro-3-(trifluoromethyl)phenyl]-3,3-dimethylpyrrolidine2,5-dione (29). To a solution of 3,3-dimethylpyrrolidine-2,5-dione (47) $(1.71 \mathrm{~g}, 13.5 \mathrm{mmol})$ and $\mathrm{Cu}_{2} \mathrm{O}(0.74 \mathrm{~g}, 5.2 \mathrm{mmol})$ in DMF $(15$ $\mathrm{mL}$ ) was added 1-fluoro-4-iodo-2-(trifluoromethyl)benzene (45) (3.0 g, $10.3 \mathrm{mmol}$ ), and the mixture was heated to reflux for $48 \mathrm{~h}$. After cooling to rt, the solvent was evaporated in vacuo. After addition of concentrated $\mathrm{NH}_{4} \mathrm{OH}(20 \mathrm{~mL})$ and $\mathrm{H}_{2} \mathrm{O}(15 \mathrm{~mL})$, the resulting precipitate was filtered and purified by chromatography (sg, hexane:EtOAc, 5:1) to afford 29 as a white solid (1.39 g, 46\%). mp $134-136{ }^{\circ} \mathrm{C} ;{ }^{1} \mathrm{H} \operatorname{NMR}\left(\mathrm{CDCl}_{3}\right) \delta 1.44(\mathrm{~s}, 6 \mathrm{H}), 2.74(\mathrm{~s}, 2 \mathrm{H}), 7.33(\mathrm{t}, J$ $=9.3 \mathrm{~Hz}, 1 \mathrm{H}), 7.53-7.56(\mathrm{~m}, 1 \mathrm{H}), 7.62(\mathrm{~d}, J=5.9 \mathrm{~Hz}, 1 \mathrm{H}) ;{ }^{13} \mathrm{C} \mathrm{NMR}$ $\left(\mathrm{CDCl}_{3}\right) \delta 25.60,40.23,43.62,117.67(\mathrm{~d}, J=22.1 \mathrm{~Hz}), 119.15(\mathrm{qd}, J=$ $34.6,13.4 \mathrm{~Hz}), 121.95(\mathrm{q}, J=272.5 \mathrm{~Hz}), 125.33(\mathrm{~m}), 128.0(\mathrm{~d}, J=3.8$ $\mathrm{Hz}), 131.9(\mathrm{~d}, J=8.6 \mathrm{~Hz}), 158.89$ (d, $J=258.6 \mathrm{~Hz}), 174.20,181.67$. Anal. Calcd for $\mathrm{C}_{13} \mathrm{H}_{11} \mathrm{~F}_{4} \mathrm{NO}_{2}$ : C, 53.99; $\mathrm{H}, 3.83 ; \mathrm{N}, 4.84$; Found: $\mathrm{C}$, 54.00; H, 3.82; N, 4.89 .

3-[4-Fluoro-3-(trifluoromethyl)phenyl]-5,5-dimethyloxazolidine2,4-dione (30). To a solution of 5,5-dimethyloxazolidine-2,4-dione (54) $(903 \mathrm{mg}, 7.0 \mathrm{mmol})$ and $\mathrm{Cu}(\mathrm{OAc})_{2}(90 \mathrm{mg}, 0.5 \mathrm{mmol})$ in methanol $(25 \mathrm{~mL})$ was added (4-fluoro-3-(trifluoromethyl)phenyl)boronic acid (53) $(1.04 \mathrm{~g}, 5.0 \mathrm{mmol})$ under $\mathrm{O}_{2}$. The mixture was heated at $70{ }^{\circ} \mathrm{C}$ overnight. After cooling to $\mathrm{rt}$, the solvent was evaporated in vacuo. The residue was purified by chromatography with successive elution with hexane and EtOAc followed by crystallization from 1:10 ethanol: $\mathrm{H}_{2} \mathrm{O}$ to afford 30 as a white solid $(421 \mathrm{mg}, 29 \%)$. mp $174-176{ }^{\circ} \mathrm{C} ;{ }^{1} \mathrm{H}$ NMR $\left(\mathrm{CDCl}_{3}\right) \delta 1.70(\mathrm{~s}, 6 \mathrm{H}), 7.34(\mathrm{t}, J=8.8$ $\mathrm{Hz}, 1 \mathrm{H}), 7.69-7.72(\mathrm{~m}, 1 \mathrm{H}), 7.79(\mathrm{dd}, J=2.4,5.9 \mathrm{~Hz}, 1 \mathrm{H}) ;{ }^{13} \mathrm{C}$ NMR $\left(\mathrm{CDCl}_{3}\right) \delta 23.74,83.80,117.99(\mathrm{~d}, J=22.1 \mathrm{~Hz}), 119.48(\mathrm{qd}, J=34.1$, $20.2 \mathrm{~Hz}), 121.81(\mathrm{q}, J=272.5 \mathrm{~Hz}), 124.53(\mathrm{~m}), 127.12(\mathrm{~d}, J=3.4$ $\mathrm{Hz}), 130.89(\mathrm{~d}, J=9.1 \mathrm{~Hz}), 152.54,159.01(\mathrm{dq}, J=259.6,1.9 \mathrm{~Hz})$, 174.32. Anal. Calcd for $\mathrm{C}_{12} \mathrm{H}_{9} \mathrm{~F}_{4} \mathrm{NO}_{3}$ : C, 49.49; H, 3.12; N, 4.81; Found: C, 49.21; H, 3.06; N, 4.80.

3-[4-Fluoro-3-(trifluoromethyl)phenyl]-5,5-dimethylpyrrolidine2,4-dione (31). Step 1. A mixture of 2-[4-fluoro-3-(trifluoromethyl)- 
phenyl]acetic acid $(2.22 \mathrm{~g}, 10 \mathrm{mmol})$ and $\mathrm{SOCl}_{2}(4 \mathrm{~mL})$ was stirred at $80{ }^{\circ} \mathrm{C}$ overnight. The reaction mixture was concentrated in vacuo to afford 2-[4-fluoro-3-(trifluoromethyl)phenyl] acetyl chloride (65), which was used for the next step without further purification. Step 2. To a solution of methyl 2-amino-2-methylpropanoate $\mathrm{HCl}$ salt $(1.53 \mathrm{~g}, 10 \mathrm{mmol})$ and $\mathrm{Et}_{3} \mathrm{~N}(5.0 \mathrm{~g}, 50 \mathrm{mmol})$ in THF $(47.5 \mathrm{~mL})$ was added 65 in THF $(2.5 \mathrm{~mL})$, and the reaction mixture was stirred at $\mathrm{rt}$ overnight. After filtration to remove insoluble TEA $\mathrm{HCl}$ salt, the filtrate was concentrated in vacuo. The residue was purified by chromatography (sg, EtOAc:hexane, 1:1) to afford methyl 2-[2-[4fluoro-3-(trifluoromethyl)phenyl] acetamido]-2-methylpropanoate (66) as a white solid $(1.13 \mathrm{~g}, 35 \%) .{ }^{1} \mathrm{H}$ NMR (DMSO- $\left.d_{6}\right) \delta 1.35$ (s, $6 \mathrm{H}), 3.50(\mathrm{~s}, 3 \mathrm{H}), 3.52(\mathrm{~s}, 2 \mathrm{H}), 7.45(\mathrm{dd}, J=10.9,8.6 \mathrm{~Hz}, 1 \mathrm{H}), 7.52-$ $7.61(\mathrm{~m}, 1 \mathrm{H}), 7.63(\mathrm{~d}, J=7.7 \mathrm{~Hz}, 1 \mathrm{H}), 8.54(\mathrm{~s}, 1 \mathrm{H})$. Step 3. To a solution of $66(860 \mathrm{mg}, 2.68 \mathrm{mmol})$ in THF $(7 \mathrm{~mL})$ was added a suspension of $\mathrm{NaH}(300 \mathrm{mg}, 12.5 \mathrm{mmol})$ in THF $(6.4 \mathrm{~mL})$ dropwise under Ar. The reaction mixture was stirred at rt for 12 before quenching with a mixture of acetic acid $(1.2 \mathrm{~g}, 20 \mathrm{mmol})$ and $\mathrm{H}_{2} \mathrm{O}(1$ $\mathrm{mL}$ ). Solvent removal in vacuo gave a crude product which was crystallized from hexane to afford 31 as a white solid (406 mg, 52\%). mp 217-219 ${ }^{\circ} \mathrm{C} ;{ }^{1} \mathrm{H}$ NMR (DMSO- $\left.d_{6}\right) \delta 1.36(\mathrm{~s}, 6 \mathrm{H}), 7.46(\mathrm{dd}, J=$ $10.8,8.9 \mathrm{~Hz}, 1 \mathrm{H}), 7.83(\mathrm{~s}, 1 \mathrm{H}), 8.30-8.40(\mathrm{~m}, 1 \mathrm{H}), 8.47(\mathrm{dd}, J=7.4$, $2.2 \mathrm{~Hz}, 1 \mathrm{H}), 11.68(\mathrm{~s}, 1 \mathrm{H}) .{ }^{13} \mathrm{C}$ NMR (DMSO- $\left.d_{6}\right) \delta 24.54,56.49$, 98.64, $115.88(\mathrm{qd}, J=31.8,12.2 \mathrm{~Hz}), 116.56(\mathrm{~d}, J=20.1 \mathrm{~Hz}), 122.87$ $(\mathrm{q}, J=271.4 \mathrm{~Hz}), 124.55(\mathrm{q}, J=4.8 \mathrm{~Hz}), 129.75(\mathrm{~d}, J=3.7 \mathrm{~Hz})$, $132.87(\mathrm{~d}, J=8.0 \mathrm{~Hz}), 156.37(\mathrm{~d}, J=250.9 \mathrm{~Hz}), 170.39,176.13$. Anal. Calcd for $\mathrm{C}_{13} \mathrm{H}_{11} \mathrm{~F}_{4} \mathrm{NO}_{2}$ : C, 53.99; H, 3.83; N, 4.84. Found: C, 54.09; $\mathrm{H}, 3.92 ; \mathrm{N}, 4.60$.

1-[4-Fluoro-3-(trifluoromethyl)phenyl]-4,4-dimethylimidazolidin2-one (32). To a solution of 4,4-dimethyl-2-imidazolidinone (48) (500 mg, $4.4 \mathrm{mmol}), \mathrm{Cs}_{2} \mathrm{CO}_{3}(2.460 \mathrm{~g}, 7.5 \mathrm{mmol})$, Xantphos (108 mg, $0.19 \mathrm{mmol})$, and $\mathrm{Pd}_{2}(\mathrm{dba})_{3}(84 \mathrm{mg}, 0.09 \mathrm{mmol})$ in toluene $(40 \mathrm{~mL})$ was added 1-fluoro-4-iodo-2-(trifluoromethyl)benzene (45) (1.270 g, $4.4 \mathrm{mmol})$. The reaction mixture was stirred at $90{ }^{\circ} \mathrm{C}$ for $12 \mathrm{~h}$ under Ar. Evaporation gave a crude product which was purified by washing with water $(25 \mathrm{~mL})$, chromatography ( $\mathrm{sg}$, EtOAc), and recrystallizion from hexane to afford 32 as a white solid (939 mg, 77\%). mp 147-148 ${ }^{\circ} \mathrm{C}$; ${ }^{1} \mathrm{H}$ NMR (DMSO- $\left.d_{6}\right) \delta 1.28(\mathrm{~s}, 6 \mathrm{H}), 3.64(\mathrm{~s}, 2 \mathrm{H}), 7.39(\mathrm{~s}, 1 \mathrm{H})$, $7.45(\mathrm{t}, J=9.8 \mathrm{~Hz}, 1 \mathrm{H}), 7.72(\mathrm{dt}, J=9.2,3.6 \mathrm{~Hz}, 1 \mathrm{H}), 8.05(\mathrm{dd}, J=$ 6.4, $2.9 \mathrm{~Hz}, 1 \mathrm{H}$ ); ${ }^{13} \mathrm{C}$ NMR (DMSO- $d_{6}$ ) $\delta 28.20,50.57,57.07,114.69$ $(\mathrm{q}, J=5.2 \mathrm{~Hz}), 116.22(\mathrm{qd}, J=32.1,12.9 \mathrm{~Hz}), 117.29(\mathrm{~d}, J=21.3 \mathrm{~Hz})$, $122.30(\mathrm{~d}, J=7.7 \mathrm{~Hz}), 122.66(\mathrm{q}, J=272.3 \mathrm{~Hz}), 137.58,153.26(\mathrm{~d}, J=$ 247.5 Hz), 157.02. Anal. Calcd for $\mathrm{C}_{12} \mathrm{H}_{12} \mathrm{~F}_{4} \mathrm{~N}_{2} \mathrm{O}$ : C, 52.18; H, 4.38; N, 10.14. Found: C, 52.32; H, 4.57; N, 10.26.

1-[4-Fluoro-3-(trifluoromethyl)phenyl]-5,5-dimethylimidazolidine-2,4-dione (33). Step 1. To a mixture of 4-fluoro-3(trifluoromethyl)aniline (63) (1.791 g, $10 \mathrm{mmol}$ ), formamide (50 $\mathrm{mL})$, and acetone $(25 \mathrm{~mL})$ was added $1 \mathrm{M} \mathrm{TiCl}_{4}$ in $\mathrm{CH}_{2} \mathrm{Cl}_{2}(12.5 \mathrm{~mL})$ at $0{ }^{\circ} \mathrm{C}$ under Ar. After $1 \mathrm{~h}, \mathrm{Zn}$ powder $(1.5 \mathrm{~g}, 23 \mathrm{mmol})$ was added followed by dropwise addition of $50 \% \mathrm{H}_{2} \mathrm{O}_{2}(1.75 \mathrm{~mL})$ in formamide (23.25 mL) over $3 \mathrm{~h}$. The reaction was quenched with $\mathrm{H}_{2} \mathrm{O}(25 \mathrm{~mL})$, and the $\mathrm{pH}$ adjusted to 8 with concentrated ammonium hydroxide followed by extraction with EtOAc $(3 \times 50 \mathrm{~mL})$. The combined organic layers were concentrated in vacuo, and the residue was dissolved in $\mathrm{CHCl}_{3}(100 \mathrm{~mL})$. The solution was then washed with $\mathrm{H}_{2} \mathrm{O}(3 \times 25 \mathrm{~mL})$. Evaporation gave a crude product which was further purified by successive recrystallizations from a mixture of $\mathrm{CH}_{2} \mathrm{Cl}_{2}(5 \mathrm{~mL})$ and hexane $(1 \mathrm{~mL})$ and a mixture of acetic acid $(150$ $\mathrm{mg})$ and $\mathrm{H}_{2} \mathrm{O}(1 \mathrm{~mL})$ to afford 2-[[4-fluoro-3-(trifluoromethyl)phenyl]amino]-2-methylpropanamide $(66)$ as a white solid $(418 \mathrm{mg}$, $16 \%) ;{ }^{1} \mathrm{H}$ NMR (DMSO- $\left.d_{6}\right) \delta 1.35(\mathrm{~s}, 6 \mathrm{H}), 6.18(\mathrm{~s}, 1 \mathrm{H}), 6.71(\mathrm{dt}, J=$ 9.0, 3.6 Hz, 1H), $6.81(\mathrm{dd}, J=6.0,3.0 \mathrm{~Hz}, 1 \mathrm{H}), 7.05(\mathrm{~s}, 1 \mathrm{H}), 7.22(\mathrm{t}, J$ $=9.8 \mathrm{~Hz}, 1 \mathrm{H}), 7.34(\mathrm{~s}, 1 \mathrm{H}) .{ }^{13} \mathrm{C}$ NMR $\left(\right.$ DMSO-d $\left.d_{6}\right) \delta 25.22,56.63$, $111.09(\mathrm{q}, J=4.7 \mathrm{~Hz}), 116.20(\mathrm{qd}, J=31.5,13.0 \mathrm{~Hz}), 117.16(\mathrm{~d}, J=$ $21.2 \mathrm{~Hz}), 118.79(\mathrm{~d}, J=7.4 \mathrm{~Hz}), 122.92(\mathrm{q}, J=272.0 \mathrm{~Hz}), 143.20(\mathrm{~d}, J$ $=1.9 \mathrm{~Hz}), 150.44(\mathrm{dq}, J=241.0,2.4 \mathrm{~Hz}), 177.13$. Step 2. To a solution of $66(160 \mathrm{mg}, 0.6 \mathrm{mmol})$ in toluene $(5 \mathrm{~mL})$ was added 2isocyanato-1,3-diisopropylbenzene $(143 \mathrm{mg}, 0.7 \mathrm{mmol})$. After the mixture was heated to $250{ }^{\circ} \mathrm{C}$ at 5 bar for $10 \mathrm{~min}$ under microwave irradiation in a sealed tube, the solvent was evaporated in vacuo. The residue was purified by sg chromatography eluting successively with $\mathrm{CH}_{2} \mathrm{Cl}_{2}$ and $1: 3$ acetone:hexane to afford 33 as a white solid $(108 \mathrm{mg}$, 62\%). mp 193-195 ${ }^{\circ} \mathrm{C} ;{ }^{1} \mathrm{H}$ NMR (DMSO-d $\left.d_{6}\right) \delta 1.34(\mathrm{~s}, 6 \mathrm{H}), 7.63(\mathrm{t}$, $J=9.7 \mathrm{~Hz}, 1 \mathrm{H}), 7.71-7.78(\mathrm{~m}, 1 \mathrm{H}), 7.84(\mathrm{dd}, J=6.6,2.6 \mathrm{~Hz}, 1 \mathrm{H})$, $11.26(\mathrm{~s}, 1 \mathrm{H}) ;{ }^{13} \mathrm{C}$ NMR (DMSO- $\left.d_{6}\right) \delta 23.09,64.21,117.25$ (qd, $J=$ $32.8,13.2 \mathrm{~Hz}), 118.25(\mathrm{~d}, J=21.5 \mathrm{~Hz}), 122.18(\mathrm{q}, J=273.5 \mathrm{~Hz})$, $128.19,131.44$ (d, $J=3.4 \mathrm{~Hz}), 135.86(\mathrm{~d}, J=9.2 \mathrm{~Hz}), 154.99,157.87$ $(\mathrm{d}, J=254.8 \mathrm{~Hz})$, 177.14. Anal. Calcd for $\mathrm{C}_{12} \mathrm{H}_{10} \mathrm{~F}_{4} \mathrm{~N}_{2} \mathrm{O}_{2}: \mathrm{C}, 49.66 ; \mathrm{H}$, 3.47; N, 9.65. Found: C, 49.71, H, 3.58, N, 9.80.

3-[4-Fluoro-3-(trifluoromethyl)phenyl]-6,6-dimethyldihydropyrimidine-2,4(1H,3H)-dione (34). Step 1. To a solution of 3-amino-3methylbutanoic acid $(61)(585 \mathrm{mg}, 5.0 \mathrm{mmol})$ in $2 \mathrm{M} \mathrm{NaOH}(5 \mathrm{~mL})$ was added $56(1.95 \mathrm{~g}, 9.5 \mathrm{mmol})$. After it was stirred at $\mathrm{rt}$ for $4 \mathrm{~h}$, the reaction mixture was filtered to remove the insoluble $\mathrm{N}, \mathrm{N}$-diarylurea side product, and the filtrate was adjusted to $\mathrm{pH} 1.0$ with $2 \mathrm{M} \mathrm{HCl}$ and concentrated. Step 2. The residue was suspended in $2 \mathrm{M} \mathrm{HCl}(50 \mathrm{~mL})$ and then heated at $110{ }^{\circ} \mathrm{C}$ for $2 \mathrm{~h}$. After the reaction mixture was cooled to rt, the resulting precipitate was filtered and washed with $\mathrm{H}_{2} \mathrm{O}(20 \mathrm{~mL})$ to give 34 as a white solid $(477 \mathrm{mg}, 31 \%)$. mp 225-226 ${ }^{\circ} \mathrm{C} ;{ }^{1} \mathrm{H}$ NMR (DMSO- $\left.d_{6}\right) \delta 1.31(\mathrm{~s}, 6 \mathrm{H}), 2.74(\mathrm{~s}, 2 \mathrm{H}), 7.53-7.64(\mathrm{~m}$, $2 \mathrm{H}), 7.71(\mathrm{dd}, J=6.7,2.4 \mathrm{~Hz}, 1 \mathrm{H}), 8.18(\mathrm{~s}, 1 \mathrm{H}) ;{ }^{13} \mathrm{C}$ NMR (DMSO$\left.d_{6}\right) \delta 28.11,44.32,48.22,116.88(\mathrm{qd}, J=32.6,13.3 \mathrm{~Hz}), 117.68(\mathrm{~d}, J=$ $21.5 \mathrm{~Hz}), 122.54(\mathrm{q}, J=272.3 \mathrm{~Hz}), 128.60(\mathrm{~d}, J=4.8 \mathrm{~Hz}), 132.82(\mathrm{~d}, J$ $=3.5 \mathrm{~Hz}), 136.61(\mathrm{~d}, J=9.1 \mathrm{~Hz}), 152.51,158.16(\mathrm{~d}, J=254.0 \mathrm{~Hz})$, 169.81. Anal. Calcd for $\mathrm{C}_{13} \mathrm{H}_{12} \mathrm{~F}_{4} \mathrm{~N}_{2} \mathrm{O}_{2} 0.5 \mathrm{H}_{2} \mathrm{O}: \mathrm{C}, 49.85 ; \mathrm{H}, 4.18$; N, 8.94. Found: C, 49.79; H, 4.51; N, 8.81.

3-[4-Fluoro-3-(trifluoromethyl)phenyl]-5,5-dimethyldihydropyrimidine-2,4(1H,3H)-dione (35). Step 1 . To a solution of 3-amino-2,2dimethylpropanoic acid hydrochloride $(62)(700 \mathrm{mg}, 4.6 \mathrm{mmol})$ in 2 $\mathrm{M} \mathrm{NaOH}(5 \mathrm{~mL})$ was added $56(1.95 \mathrm{~g}, 9.5 \mathrm{mmol})$, and the reaction mixture was stirred at $\mathrm{rt}$ for $4 \mathrm{~h}$. After filtration to remove the insoluble $\mathrm{N}, \mathrm{N}$-diarylurea side product, the filtrate was adjusted to $\mathrm{pH} 1.0$ with 2 $\mathrm{M} \mathrm{HCl}$ and concentrated to afford 3-[3-[4-fluoro-3-(trifluoromethyl)phenyl]ureido]-2,2-dimethylpropanoic acid $(480 \mathrm{mg}, 32 \%)$ as a white solid. ${ }^{1} \mathrm{H}$ NMR (DMSO- $\left.d_{6}\right) \delta 1.09(\mathrm{~s}, 6 \mathrm{H}), 3.22(\mathrm{~d}, J=6.2 \mathrm{~Hz}, 2 \mathrm{H})$, $6.25(\mathrm{t}, J=6.2 \mathrm{~Hz}, 1 \mathrm{H}), 7.36(\mathrm{t}, J=9.8 \mathrm{~Hz}, 1 \mathrm{H}), 7.43-7.53(\mathrm{~m}, 1 \mathrm{H})$, $7.95(\mathrm{dd}, J=6.5,2.8 \mathrm{~Hz}, 1 \mathrm{H}), 8.99(\mathrm{~s}, 1 \mathrm{H}), 12.39(\mathrm{~s}, 1 \mathrm{H})$. Step 2. 3[3-[4-Fluoro-3-(trifluoromethyl)phenyl]ureido]-2,2-dimethylpropanoic acid $(450 \mathrm{mg}, 1.4 \mathrm{mmol})$ was suspended in $2 \mathrm{M} \mathrm{HCl}(50 \mathrm{~mL})$ and then heated at $110{ }^{\circ} \mathrm{C}$ for $12 \mathrm{~h}$. After the reaction mixture was cooled to $\mathrm{rt}$, the resulting precipitate was filtered and washed with saturated $\mathrm{NaHCO}_{3}(30 \mathrm{~mL})$ to give 35 as a white solid $(355 \mathrm{mg}$, 83\%). mp 214-215 ${ }^{\circ} \mathrm{C} ;{ }^{1} \mathrm{H}$ NMR (DMSO- $\left.d_{6}\right) \delta 1.21(\mathrm{~s}, 6 \mathrm{H}), 3.18$ (s, $1 \mathrm{H}), 3.18(\mathrm{~d}, J=2.8 \mathrm{~Hz}, 1 \mathrm{H}), 7.52-7.59(\mathrm{~m}, 2 \mathrm{H}), 7.63-7.69(\mathrm{~m}$, $1 \mathrm{H}), 8.11(\mathrm{~s}, 1 \mathrm{H}) ;{ }^{13} \mathrm{C}$ NMR (DMSO- $\left.d_{6}\right) \delta 22.35,37.39,46.31$, $116.60(\mathrm{qd}, J=32.9,13.7 \mathrm{~Hz}), 117.41(\mathrm{~d}, J=21.5 \mathrm{~Hz}), 122.34(\mathrm{q}, J=$ $271.9 \mathrm{~Hz}), 128.34,133.07(\mathrm{~d}, J=3.5 \mathrm{~Hz}), 136.42(\mathrm{~d}, J=9.2 \mathrm{~Hz})$, 153.02, $157.88(\mathrm{~d}, J=253.6 \mathrm{~Hz})$, 175.33. Anal. Calcd for $\mathrm{C}_{13} \mathrm{H}_{12} \mathrm{~F}_{4} \mathrm{~N}_{2} \mathrm{O}_{2}$ : C, 51.32; H, 3.98; N, 9.21. Found: C, 51.19; H, 3.99; N, 9.12 .

2-[3-[4-Fluoro-3-(trifluoromethyl)phenyl]ureido]-2-methylpropanoic acid (36). Hydantoin 1 ( $1.20 \mathrm{~g}, 4.1 \mathrm{mmol})$ was added to $2 \mathrm{M}$ $\mathrm{NaOH}(40 \mathrm{~mL})$. The reaction mixture was stirred at $\mathrm{rt}$ for $4 \mathrm{~h}$, and then quenched with $2 \mathrm{M} \mathrm{HCl}(50 \mathrm{~mL})$. The precipitate was filtered and rinsed with $\mathrm{H}_{2} \mathrm{O}(20 \mathrm{~mL})$ and then dried to afford 36 as a white solid (1.20 g, 95\%). mp 196.5-197.5 ${ }^{\circ} \mathrm{C} ;{ }^{1} \mathrm{H}$ NMR (DMSO- $\left.d_{6}\right) \delta 1.43$ $(\mathrm{s}, 6 \mathrm{H}), 6.61(\mathrm{~s}, 1 \mathrm{H}), 7.37(\mathrm{t}, J=9.8 \mathrm{~Hz}, 1 \mathrm{H}), 7.47-7.50(\mathrm{~m}, 1 \mathrm{H})$, 7.96-7.97 (m, 1H), $8.87(\mathrm{~s}, 1 \mathrm{H}), 12.44(\mathrm{~s}, 1 \mathrm{H}) ;{ }^{13} \mathrm{C}$ NMR (DMSO$\left.d_{6}\right) \delta 25.42,55.13,115.12(\mathrm{~d}, J=5.0 \mathrm{~Hz}), 116.45(\mathrm{qd}, J=31.6,12.8$ $\mathrm{Hz}), 117.65(\mathrm{~d}, J=21.5 \mathrm{~Hz}), 122.85(\mathrm{q}, J=272.1 \mathrm{~Hz}), 123.42(\mathrm{~d}, J=$ $7.8 \mathrm{~Hz}), 137.34,153.32(\mathrm{~d}, J=246.9 \mathrm{~Hz}), 154.37,176.31$. Anal. Calcd for $\mathrm{C}_{12} \mathrm{H}_{12} \mathrm{~F}_{4} \mathrm{~N}_{2} \mathrm{O}_{3}$ : C, 46.76; $\mathrm{H}, 3.92 ; \mathrm{N}, 9.09$. Found: $\mathrm{C}, 46.50 ; \mathrm{H}$, 4.04; N, 9.19.

Polar Surface Area (PSA). PSA values $\left(\AA^{2}\right)$ were calculated using ChemAxon Instant JChem (ver 16.4).

Kinetic Solubility. Compounds in DMSO $(10 \mathrm{mg} / \mathrm{mL})$ were diluted into either $\mathrm{pH} 6.5$ phosphate buffer or $0.01 \mathrm{M} \mathrm{HCl}$ (approximately $\mathrm{pH} 2.0$ ), with the final DMSO concentration being $1 \%$. Samples were then analyzed via nephelometry to determine a solubility range. ${ }^{45}$ 
Partition Coefficient. Partition coefficient values $(\log D)$ of the test compounds were estimated by correlation of their chromatographic retention properties against the characteristics of a series of standard compounds with known partition coefficient values using gradient HPLC (modification of a method reported by Lombardo et al. $^{46}$

Plasma Protein Binding. Plasma protein binding values of the test compounds were estimated by correlation of their chromatographic retention properties on a human albumin column against the characteristics of a series of standard compounds with known protein binding values. The method employed is a gradient HPLC based derivation of the method developed by Valko et al. ${ }^{47}$

In Vitro Metabolic Stability. Metabolic stability assays were performed by incubating test compounds in liver microsomes at $37^{\circ} \mathrm{C}$ and $0.4 \mathrm{mg} / \mathrm{mL}$ protein concentration. The metabolic reaction was initiated by the addition of an NADPH-regenerating system and quenched at various time points over a $60 \mathrm{~min}$ incubation period by the addition of acetonitrile containing diazepam as internal standard. Control samples (containing no NADPH) were included (and quenched at 2, 30, and $60 \mathrm{~min}$ ) to monitor for potential degradation in the absence of cofactor. Compound concentrations were determined by LC/MS by comparison to calibration standards prepared in prequenched microsomal matrix.

Mouse Exposure Studies. Pharmacokinetic studies in mice were conducted at Monash University, Parkville, Australia, and were performed in accordance with the Australian Code of Practice for the Care and Use of Animals for Scientific Purposes. The study protocol adhered to the principles of reduction, refinement, and replacement and was approved by the Monash Institute of Pharmaceutical Sciences Animal Ethics Committee. The systemic exposure of the aryl hydantoins was studied in nonfasted male Swiss outbred mice weighing 25-33 g (7 mice per compound). Mice had access to food and water ad libitum throughout the pre- and postdose sampling period. Formulations were prepared by dispersing the aryl hydantoins in Tween 80 and then adding ethanol and Milli- $Q$ water (final composition 7\% v/v Tween 80, 3\% v/v ethanol). Following vortexing and sonication, samples formed either uniform suspensions $(1-3,14,16,23,26)$ or a colorless solution (13). Compound formulations were mixed by inverting the tubes prior to drawing each dosing volume. All animals were dosed orally by gavage $(10 \mathrm{~mL} / \mathrm{kg}$ dose volume) within $1 \mathrm{~h}$ of formulation preparation. Following administration, blood samples were collected from 0.25 to $48 \mathrm{~h}$ postdose ( $n=2$ mice per time point). A maximum of two samples were obtained from each mouse, with samples being taken either via submandibular bleed (approximately $120 \mu \mathrm{L}$; conscious sampling) or terminal cardiac puncture $(0.6 \mathrm{~mL}$; while mice were under deep anesthesia using inhaled isoflurane). No urine samples were collected, as mice were housed in bedded cages during the study. Blood was collected directly into polypropylene Eppendorf tubes containing heparin as anticoagulant and stabilization cocktail (containing Complete (a protease inhibitor cocktail), potassium fluoride, and EDTA) to minimize the potential for ex vivo degradation of the aryl hydantoins in blood/plasma samples. Once collected, blood samples were centrifuged immediately, and supernatant plasma was removed and stored at $-80{ }^{\circ} \mathrm{C}$ until analysis by LCMS. Plasma concentrations were determined by comparison to calibration standards prepared in blank plasma and treated the same as the plasma samples. Plasma concentration-time data were analyzed using noncompartmental methods (PKSolver Version 2.0).

S. mansoni in Vivo Studies. The in vivo study was approved by the local veterinary agency, based on Swiss cantonal and national regulations (permission no. 2070). As described by Keiser, ${ }^{48}$ cercariae of S. mansoni were obtained from infected Biomphalaria glabrata. NMRI mice were infected subcutaneously with approximately $100 \mathrm{~S}$. mansoni cercariae. At $49 \mathrm{~d}$ after infection, groups of four mice were treated with single $100 \mathrm{mg} / \mathrm{kg}$ oral doses of compounds in a $7 \%(\mathrm{v} / \mathrm{v})$ Tween $80 \%$ and $3 \%(\mathrm{v} / \mathrm{v})$ ethanol vehicle $(10 \mathrm{~mL} / \mathrm{kg})$. Untreated mice $(n=8)$ served as controls. At $21 \mathrm{~d}$ post-treatment, animals were killed by the $\mathrm{CO}_{2}$ method and dissected. Worms were removed by picking, then sexed and counted.
Androgen-Dependent Cell-Based Assay. As described by Jones and Diamond, ${ }^{49}$ LAPC4 cells were cultured in phenol red free RPMI 1640 media supplemented with antibiotics and 10\% FBS. For all transfections, pools of cells were transfected using Lipofectamine Plus (Invitrogen) with PSA-luciferase ${ }^{50}$ and pRL-SV40 (Promega) as a normalization control. The following day, the cells were replated, 0.3 $\mathrm{nM}$ DHT and test compounds were added, and $24 \mathrm{~h}$ later luciferase production was measured (Dual luciferase assay kit; Promega), normalizing the firefly signal to the renilla signal. Mean-effect plots (log[compound] vs $\log [$ fractional effect]) were generated to determine the $\mathrm{IC}_{50}$ values for each test compound or combinations of test compounds at constant ratios.

\section{ASSOCIATED CONTENT}

\section{Supporting Information}

The Supporting Information is available free of charge on the ACS Publications website at DOI: 10.1021/acs.jmedchem.6b01410.

$$
\text { SMILES data (CSV) }
$$

\section{AUTHOR INFORMATION}

\section{Corresponding Author}

*Tel: 402.559.5362. Fax: 402.559.9543. Email: jvenners@ unmc.edu.

ORCID $\odot$

Jonathan L. Vennerstrom: 0000-0003-0075-2336

\section{Present Address}

For Q.Z.: Shanghai Institute of Materia Medica, Chinese Academy of Sciences, No. 501, Haike Rd., Pudong New District, Shanghai 201210, China.

\section{Notes}

The authors declare no competing financial interest.

\section{ACKNOWLEDGMENTS}

We acknowledge the U.S. National Institutes of Health (AI097802-02 and AI116723-01) and the European Research Council (ERC-2013-CoG 614739-A HERO) for financial support.

\section{ABBREVIATIONS USED}

$\mathrm{AR}$, androgen receptor; DMA, dimethylacetamide; N, nilutamide; PZ, praziquantel; WBR, worm burden reduction

\section{REFERENCES}

(1) Hotez, P. J.; Brindley, P. J.; Bethony, J. M.; King, C. H.; Pearce, E. J.; Jacobson, J. Helminth infections: The great neglected tropical diseases. J. Clin. Invest. 2008, 118, 1311-1321.

(2) Gryseels, B. Schistosomiasis. Infect. Dis. Clin. North Am. 2012, 26, 383-397.

(3) Colley, D. G.; Bustinduy, A. L.; Secor, W. E.; King, C. H. Human schistosomiasis. Lancet 2014, 383, 2253-2264.

(4) Utzinger, J.; N'goran, E. K.; Caffrey, C. R.; Keiser, J. From innovation to application: Social-ecological context, diagnostics, drugs and integrated control of schistosomiasis. Acta Trop. 2011, 120, S121S137.

(5) Olliaro, P.; Delgado-Romero, P.; Keiser, J. The little we know about the pharmacokinetics and pharmacodynamics of praziquantel (racemate and R-enantiomer). J. Antimicrob. Chemother. 2014, 69, 863-870.

(6) Cioli, D.; Pica-Mattoccia, L.; Basso, A.; Guidi, A. Schistosomiasis control: Praziquantel forever? Mol. Biochem. Parasitol. 2014, 195, $23-$ 29.

(7) Melman, S. D.; Steinauer, M. L.; Cunningham, C.; Kubatko, L. S.; Mwangi, I. N.; Wynn, N. B.; Mutuku, M. W.; Karanja, D. M.; Colley, 
D. G.; Black, C. L.; Secor, W. E.; Mkoji, G. M.; Loker, E. S. Reduced susceptibility to praziquantel among naturally occurring Kenyan isolates of Schistosoma mansoni. PLoS Neglected Trop. Dis. 2009, 3, e504.

(8) Kasinathan, R. S.; Greenberg, R. M. Pharmacology and potential physiological significance of schistosome multidrug resistance transporters. Exp. Parasitol. 2012, 132, 2-6.

(9) Caffrey, C. R.; Williams, D. L.; Todd, M. H.; Nelson, D. L.; Utzinger, J. Chemotherapeutic development strategies for schistosomiasis. In Antiparasitic and Antibacterial Drug Discovery; Selzer, P. M., Ed.; Wiley-Blackwell: Weinheim, 2009; pp 301-321.

(10) Abdulla, M.-H.; Ruelas, D. S.; Wolff, B.; Snedecor, J.; Lim, K.-C.; $\mathrm{Xu}$, F.; Renslo, A. R.; Williams, J.; McKerrow, J. H.; Caffrey, C. R. Drug discovery for schistosomiasis: Hit and lead compounds identified in a library of known drugs by medium-throughput phenotypic screening. PLoS Neglected Trop. Dis. 2009, 3, e478.

(11) Keiser, J.; Utzinger, J. Antimalarials in the treatment of schistosomiasis. Curr. Pharm. Des. 2012, 18, 3531-3538.

(12) Liu, Y.-X.; Wu, W.; Liang, Y.-J.; Jie, Z.-L.; Wang, H.; Wang, W.; Huang, Y.-X. New uses for old drugs: The tale of artemisinin derivatives in the elimination of schistosomiasis japonica in China. Molecules 2014, 19, 15058-15074.

(13) Panic, G.; Vargas, M.; Keiser, J.; Scandale, I. Activity profile of an FDA-approved compound library against Schistosoma mansoni. PLoS Neglected Trop. Dis. 2015, 9, e0003962.

(14) Thétiot-Laurent, S. A.-L.; Boissier, J.; Robert, A.; Meunier, B. Schistosomiasis Chemotherapy. Angew. Chem., Int. Ed. 2013, 52, 7936-7956.

(15) Bernauer, K.; Link, H.; Stohler, H. Antiandrogenic and schistosomicidal imidazolidine derivatives. U. S. Patent 4,234,736. 1980.

(16) Forget, E.; Félix, H.; Notteghem, M. J.; Léger, N. Appréciation de l'activité de dérivés schistosomicides en microscopie électronique. Bull. Soc. Pathol. Ex. 1982, 75, 192-200.

(17) Hansen, J. B.; Hafliger, O. Determination of the dissociation constant of a weak acid using a dissolution rate method. J. Pharm. Sci. 1983, 72, 429-431.

(18) Link, H.; Stohler, H. R. 3-Arylhydantoine, eine substanzklasse mit schistosomizider wirkung. Eur. J. Med. Chem. - Chim. Ther. 1984, 19, 261-265.

(19) Keiser, J.; Panic, G.; Vargas, M.; Wang, C.; Dong, Y.; Gautam, N.; Vennerstrom, J. L. Aryl hydantoin Ro 13-3978, a broad spectrum antischistosomal. J. Antimicrob. Chemother. 2015, 70, 1788-1797.

(20) Keiser, J.; Manneck, T.; Vargas, M. Interactions of mefloquine with praziquantel in the Schistosoma mansoni mouse model and in vitro. J. Antimicrob. Chemother. 2011, 66, 1791-1797.

(21) Keiser, J.; Vargas, M.; Vennerstrom, J. L. Activity of antiandrogens against juvenile and adult Schistosoma mansoni in mice. J. Antimicrob. Chemother. 2010, 65, 1991-1995.

(22) de Mendonça, R. L.; Escrivá, H.; Bouton, D.; Laudet, V.; Pierce, R. J. Hormones and nuclear receptors in schistosome fevelopment. Parasitol. Today 2000, 16, 233-240.

(23) Wang, C.; Zhao, Z.; Min, J.; Muniyan, X.; Vargas, M.; Wang, X.; Dong, Y.; Guy, R. K.; Lin, M.-F.; Keiser, J.; Vennerstrom, J. L. Antischistosomal versus antiandrogenic properties of aryl hydantoin Ro 13-3978. Am. J. Trop. Med. Hyg. 2014, 90, 1156-1158.

(24) Jung, M. E.; Ouk, S.; Yoo, D.; Sawyers, C. L.; Chen, C.; Tran, C.; Wongvipat, J. Structure-activity relationship for thiohydantoin androgen receptor antagonists for castration-resistant prostate cancer (CRPC). J. Med. Chem. 2010, 53, 2779-2796.

(25) Liu, B.; Su, L.; Geng, J.; Liu, J.; Zhao, G. Developments in nonsteroidal antiandrogens targeting the androgen receptor. ChemMedChem 2010, 5, 1651-1661.

(26) Vinggaard, A. M.; Niemelä, J.; Wedebye, E. B.; Jensen, G. E. Screening of 397 chemicals and development of a quantitative structure-activity relationship model for androgen receptor antagonism. Chem. Res. Toxicol. 2008, 21, 813-823.

(27) Zhang, X.; Allan, G. F.; Sbriscia, T.; Linton, O.; Lundeen, S. G.; Sui, Z. Synthesis and SAR of novel hydantoin derivatives as selective androgen receptor modulators. Bioorg. Med. Chem. Lett. 2006, 16, 5763-5766.

(28) Van Dort, M. E.; Jung, Y.-W. Synthesis and structure-activity studies of side-chain derivatized arylhydantoins for investigation as androgen receptor radioligands. Bioorg. Med. Chem. Lett. 2001, 11, $1045-1047$.

(29) Li, Q.; Wu, W.-Z.; Sun, J.; Lü, W.; Cai, J.-C. Synthesis of nilutamide and its analogue. Chin. J. Pharm. 2004, 358, 455-456.

(30) Auvin, S.; Lanco, C.; Chao, Q.; Gu, K. Preparation of novel imidazolidine-2,4-dione derivatives for treating breast or prostate cancers. Int. Pat. Appl. WO 2015100613 A1, July 92015.

(31) Muci, A. R.; Buchwald, S. L. Practical palladium catalysts for CN and $\mathrm{CO}$ bond formation. In Cross-Coupling Reactions; Miyaura, N., Ed.; Springer: MA, 2002; Vol. 219, pp 131-209.

(32) Bergauer, M.; Bertani, B.; Biagetti, M.; Bromidge, S. M.; Falchi, A.; Leslie, C. P.; Merlo, G.; Pizzi, D. A.; Rinaldi, M.; Stasi, L. P.; Tibasco, J.; Vong, A. K. K.; Ward, S. E. Preparation of quinolines and quinazolines as ligands for 5 -HT1 receptors and their use in the treatment of CNS disorders, in particular serotonin-related disorders. Int. Pat. Appl. WO 2005014552 A1, February 17, 2005.

(33) Hügel, H. M.; Rix, C. J.; Fleck, K. Comparison of copper(II) acetate promoted $\mathrm{N}$-arylation of 5,5-dimethylhydantoin and other imides with triarylbismuthanes and arylboronic acids. Synlett 2006, 14, 2290-2292.

(34) Lan, J.; Zhang, G.; Yu, X.; You, J.; Chen, L.; Yan, M.; Xie, R. A simple copper salt catalyzed $\mathrm{N}$-arylation of amines, amides, imides, and sulfonamides with arylboronic acids. Synlett 2004, 35, 1095-1097.

(35) Chan, D. M.; Monaco, K. L.; Wang, R.-P.; Winters, M. P. New $\mathrm{N}$-and $\mathrm{O}$-arylations with phenylboronic acids and cupric acetate. Tetrahedron Lett. 1998, 39, 2933-2936.

(36) Hroch, L.; Hrusková, M.; Schmitz, J.; Schnakenburg, G.; Gütschow, M. 3, 5, 5-Trisubstituted hydantoins from activated (benzyloxycarbonylamino) malonic acids. Synthesis 2012, 44, 19071914.

(37) Vystrcil, A.; Cerny, J. Model compounds of physostigmine. Collect. Czech. Chem. Commun. 1959, 24, 804-808.

(38) Pastori, N.; Greco, C.; Clerici, A.; Punta, C.; Porta, O. Freeradical addition to ketimines generated in situ. New one-pot synthesis of quaternary $\alpha$-aminoamides promoted by a $\mathrm{H}_{2} \mathrm{O}_{2} / \mathrm{TiCl}_{4}-\mathrm{Zn}$ / $\mathrm{HCONH}_{2}$ system. Org. Lett. 2010, 12, 3898-3901.

(39) Biadatti, T.; Dumais, L.; Aubert, J.; Lamy, L. Nouveaux derives de N-phenul acatamide, inhibiteurs de l'enzyme soat-1, compositions pharmaceutiques et cosmetiques les contentant. FR2920774 A1, March 13, 2009.

(40) Palm, K.; Stenberg, P.; Luthman, K.; Artursson, P. Polar molecular surface properties predict the intestinal absorption of drugs in humans. Pharm. Res. 1997, 14, 568-571.

(41) Battmann, T.; Branche, C.; Bouchoux, F.; Cerede, E.; Philibert, D.; Goubet, F.; Teutsch, G.; Gaillard-Kelly, M. Pharmacological profile of RU 58642, a potent systemic antiandrogen for the treatment of androgen-dependent disorders. J. Steroid Biochem. Mol. Biol. 1998, 64, $103-111$.

(42) Pitta, M. G.; Silva, A. C.; Neves, J. K.; Silva, P. G.; Irmão, J. I.; Malagueño, E.; Santana, J. V.; Lima, M. C.; Galdino, S. L.; Pitta, I. R.; Albuquerque, M. C. New imidazolidinic bioisosters: Potential candidates for antischistosomal drugs. Mem. Inst. Oswaldo Cruz. 2006, 101, 313-316.

(43) da Silva, A. C.; Neves, J. K.; Irmão, J. I.; Costa, V. M.; Souza, V. M.; de Medeiros, P. L.; da Silva, E. C.; de Lima, M. C. A.; Pitta, I. R.; Albuquerque, M. C.; Galdino, S. L. Study of the activity of 3-benzyl-5(4-chloro-arylazo)-4-thioxo-imidazolidin-2-one against Schistosomiasis mansoni in mice. Sci. World J. 2012, 2012, 520524.

(44) Cooper, D. G.; Porter, R. A. Preparation of glycine transporter GlyT1 inhibitors for treating neurological and neuropsychiatric disorders. Int. Pat. Appl. WO 2009034062 A1 (19 March 2009).

(45) Bevan, C. D.; Lloyd, R. S. A high-throughput screening method for the determination of aqueous drug solubility using laser nephelometry in microtiter plates. Anal. Chem. 2000, 72, 1781-1787. 
(46) Lombardo, F.; Shalaeva, M. Y.; Tupper, K. A.; Gao, F. Elog $\mathrm{D}_{\text {oct }}:$ A tool for lipophilicity determination in drug discovery. 2. Basic and neutral compounds. J. Med. Chem. 2001, 44, 2490-2497.

(47) Valko, K.; Nunhuck, S.; Bevan, C.; Abraham, M. H.; Reynolds, D. P. Fast gradient HPLC method to determine compounds binding to human serum albumin. Relationships with octanol/water and immobilized artificial membrane lipophilicity. J. Pharm. Sci. 2003, 92, $2236-2248$.

(48) Keiser, J. In vitro and in vivo trematode models for chemotherapeutic studies. Parasitology 2010, 137, 589-603.

(49) Jones, J. O.; Diamond, M. I. A cellular conformation-based screen for androgen receptor inhibitors. ACS Chem. Biol. 2008, 3, 412-418.

(50) Bolton, E. C.; So, A. Y.; Chaivorapol, C.; Haqq, C. M.; Li, H.; Yamamoto, K. R. Cell- and gene-specific regulation of primary target genes by the androgen receptor. Genes Dev. 2007, 21, 2005-2017. 